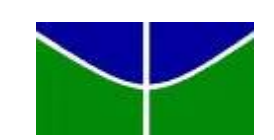

UNIVERSIDADE DE BRASÍLIA- UnB

FACULDADE DE DIREITO - FD

DA VIABILIDADE DA RELATIVIZAÇÃO

DOS DIREITOS DO HOMEM

ELIÉSIO JOSÉ DA ROCHA

BRASÍLIA - DF

2011 


\title{
DA VIABILIDADE DA RELATIVIZAÇÃO DOS DIREITOS DO HOMEM
}

\author{
ELIÉSIO JOSÉ DA ROCHA
}

Monografia apresentada, como requisito parcial para obtenção do título de Bacharel em Direitos, à Comissão Examinadora da Faculdade de Direito da Universidade de Brasília, sob a orientação do professor JULIANO BEMVINDO ZAIDEM.

BRASÍLIA - DF 2010 
Rocha, Eliésio José da.

Da viabilidade da relativização dos direitos do homem / Eliésio José da Rocha - Brasília, 2011. 60 f. : il.

Monografia (graduação) - Universidade de Brasília, Faculdade de Direito 2010. Orientador: Juliano Zaiden.

1. Direito. 2. Direitos Humanos. 3. Relatividade 


\title{
DA VIABILIDADE DA RELATIVIZAÇÃO DOS DIREITOS DO HOMEM
}

\author{
ELIÉSIO JOSÉ DA ROCHA
}

Aprovada por:

\begin{tabular}{|c|}
\hline $\begin{array}{l}\text { Profa Dr. Juliano Zaiden Benvindo } \\
\text { (orientador) } \\
\text { Faculdade de Direito da Universidade de Brasília. }\end{array}$ \\
\hline $\begin{array}{c}\text { Profo Alex Lobato Potiguar } \\
\text { Faculdade de Direito da Universidade de Brasília. }\end{array}$ \\
\hline
\end{tabular}

UNIVERSIDADE DE BRASÍLIA- UnB

FACULDADE DE DIREITO - FD 
AGRADECIMENTOS

A Deus pela graça concedida. À minha família, amigos e a todos que me incentivaram e me apoiaram ao longo dessa caminhada. E, especialmente, a meu orientador, Profa Dr. Juliano Zaiden Benvindo, por ter compartilhado os seus conhecimentos de forma tão atenciosa. 
"If I have seen farther than others, it is because I stood on the shoulders of giants." - SIR ISAAC NEWTON 


\section{RESUMO}

Os direitos humanos são tratados, pela cultura ocidental, a partir de uma perspectiva essencialista. A história da cultura e da filosofia do ocidente avoca, para si, a responsabilidade pelo desenvolvimento da tese sobre a natureza fundamental e normativa dos direitos humanos. O texto questiona esse argumento e trata a possibilidade de relativização desses direitos sob o prisma da metodologia introduzida pela Teoria da Relatividade adicionada aos conceitos de Ação Comunicativa. 


\begin{abstract}
Occidental culture deals with humans rights in an essencialist perspective. The history of culture and philosophy in the occident takes the responsibility for the developing of a foundamental and normative thesis on human rights. The text questions that argument and deals with the possibility on relativization of these rights under the optics of a methodology introduced by the Theory of Relativity in accordance with the Communicative Action.
\end{abstract}




\section{SUMÁRIO}

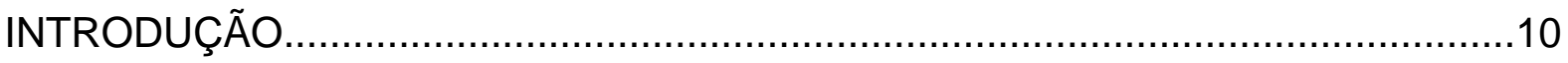

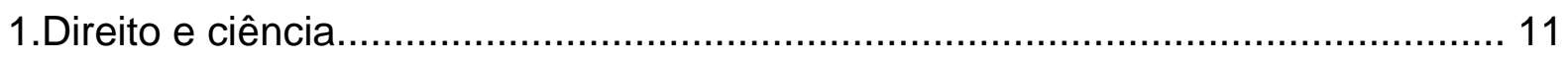

1.1 Positivismo jurídico e linguagem científica..............................................17

1.2 O problema do positivismo científico nas ciências exatas atinge o Direito?........20

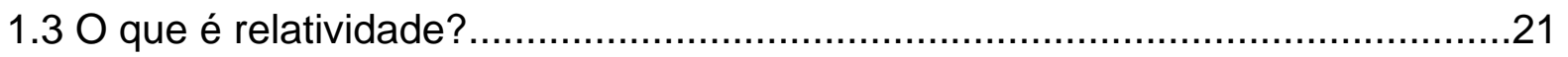

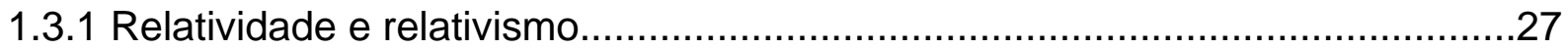

1.4 A relativização dos direitos na linguagem jurídica moderna............................29

1.4.1 O significado de se relativizar direitos..............................................31

2.Uma visão sócio-antropológica do Direito...............................................35

3.Da discussão sobre a proposição Direitos Humanos......................................38

3.1 Desenvolvimento histórico do argumento humanitário na sociedade ocidental...41

3.2 Os Direitos Humanos são criação do mundo ocidental? .45

3.3 Principais problemas a partir de uma perspectiva essencialista dos Direitos

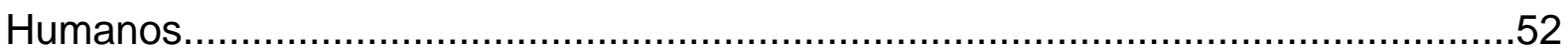

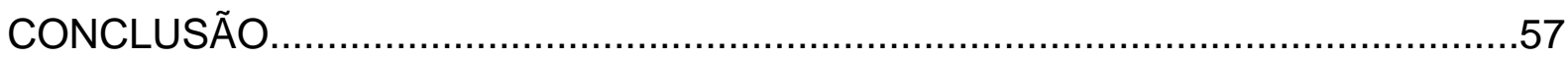

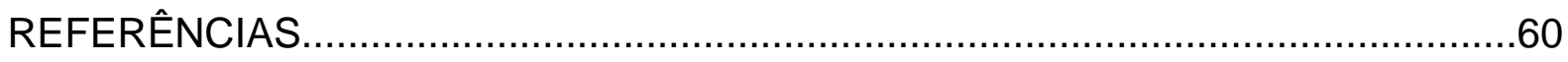




\section{INTRODUÇÃO}

Trazer à lume qualquer discussão que tenha por intento uma avaliação analítica dos Direitos Humanos constitui esforço de extremada importância para o estabelecimento de perspectivas válidas de cognição dos processos pelos quais os discursos jurídicos lançam mão, na forma de mecanismos que, articulados sob a forma institucional, compõem os estatutos fundamentais das organizações de poder que viabilizam e justificam as relações sociais e econômicos em uma determinada sociedade.

O objetivo dessas considerações é, partindo de três perspectivas epistemológicas distintas, uma histórica, uma antropológica e uma epistemológica, fixar um ponto de toque entre as culturas orientais de matriz muçulmana e as culturas de fundação ocidental européia, que permita a identificação de características valorativas comuns, visando a construção de um conjunto de elementos eticamente definidos, possibilitando a construção de uma via dialógica intercultural voltada para a eleição de fundamentos de uma razão universal dos Direitos Humanos.

Dada a escassez de tempo, aliado aos próprios objetivos dessas considerações, buscar-se-á, apenas, a constatação da existência ou falibilidade desses elementos, que podem servir de ponto de partida para a formulação de uma teoria fundamental de direitos do homem. Longe de ser um trabalho de campo, o que se buscou desenvolver, ou melhor, chamar para a discussão, foram as diversas possibilidades em que um determinado discurso pode ser metodologicamente trabalhado e, a depender do método, dar ensejo a resultados que podem ser incompatíveis entre si, podendo inclusive assumir valores antitéticos.

A introdução dessas considerações tem como objetivo mostrar o quanto de ciência há no Direito e até que ponto essa relação tem constituído obstáculo à clareza de percepção da lente jurídica acerca dos fenômenos sob os quais esta deve realmente se debruçar, objetiva-se, dessa forma, chamar atenção para a importância do estudo da epistemologia científica como pressuposto para a formulação de novas teorias jurídicas, com o fim de aprimorar, cada vez mais, os métodos de composição dos conflitos. 


\section{Direito e Ciência}

Desde que o homem, em sociedade, deu-se à percepção de que poderia encontrar explicações para os acontecimentos naturais ou sobrenaturais que o circundavam, passou a existir religião, filosofia e ciência. $\mathrm{Na}$ acepção que apresentamos, todas essas manifestações do conhecimento ou da possibilidade de conhecimento, são ciência em sentido lato.

Para os fins a que se presta esse estudo, abordamos o significante, ciência, em sentido lato, como qualquer possibilidade de acepção e aceitação dos fenômenos que circundam o homem, que possuem fundamentação justificante e justificável e que estão sujeitos à um juízo crítico cujos parâmetros são lançados como elemento fundamental de sua aceitação.

No decorrer da história humana, a possibilidade de conhecimento foi institucionalizada e foram formatados métodos de controle para que the fosse promovida ou conferida validade. Qualquer área do conhecimento, que possua pretensão de ciência ou de conhecimento válido está, necessariamente, submetida a uma espécie qualquer de método, cujo suporte lhe confere a validade argumentativa necessária para assumir um status, de integralização e validação necessários para funcionar ou funcionalizar o sistema de conhecimento de que faz parte.

Assim, o conhecimento religioso tem fundamento em escritos ecumênicos, o conhecimento filosófico em doutrinas filosóficas e o conhecimento físico em formulações matemáticas. Todos tem em comum o fato de poderem ser testados quanto à sua validade, no bojo de seus determinados sistemas, a partir dos fundamentos sob os quais foram formulados.

Dessa forma, somente é possível aceitar a validade de uma determinada proposição científica arrimado no fundamento que lhe deu existência ou concretude. Não há sentido na geometria sem o ponto, a reta e o plano, assim como não se encontrará sentido na lógica argumentativa se não for possível aceitar a verofuncionalidade dos operadores lógicos. ${ }^{1}$

\footnotetext{
1 Diz-se operador verofuncional de formação de frases qualquer operador de formação de frases que seja como $<<$ e $>>$ a esse respeito. Isto quer dizer que, dados os valores de verdade das frases concatenadas com $<<$ e $>>$ nós podemos determinar, unicamente com base nessa indicação, o valor de verdade da frase complexa resultante. Vg. Se a $<<$ e $>>$ b então b. Newton-Smith, Lógica, Um Curso Introdutório, Gradiva Publicações, 2005. p30.
} 
No Direito, esses fundamentos estão, pretensamente, assentados sobre uma racionalidade jurídica, cuja base epistemológica positivista, ou neo-positivista, tem rendido uma série de discussões acerca de sua validade normativa. Essas discussões são de extrema importância para a ciência jurídica, que está sempre a se debater entre o conjunto de normas que são colocadas à disposição de uma determinada sociedade e os métodos de validação e de legitimação do conteúdo dessas normas.

O fato de chamarmos atenção para esse problema, está diretamente relacionado com o objeto desse trabalho, que parte do pressuposto da ilegitimidade do conteúdo de determinadas normas afetas aos Direitos Humanos, por se fundamentarem sobre proposições e argumentos que não sustentam a pretensão de universalidade e de essencialidade que essas normas trazem expressas em suas intitulações.

Nesse sentido, para que uma norma internacional acerca dos direitos do homem possa se intitular Universal e Declaratória é necessário que ela se fundamente em uma razão de solidez universal, comum a todos os povos, e não apenas em termos colhidos no bojo de um determinado grupo, em um determinado tempo e, depois, impostos ao resto da humanidade como dádiva ou legado de seres superiores para a iluminação de povos que almejam ao desenvolvimento.

Para que sejamos sermos capazes de desnudar os principais problemas que são trazidos pela noção de razão jurídica, e que possui fundamentos essencialmente fincados na sociedade ocidental, é que pretendemos, aqui, continuar com nossa imersão nos conceitos de razão, Direito e modernidade, expondo os principais questionamentos à razão, principalmente aquela de matriz positivista, e de que forma tem-se procurado superar suas limitações.

A crise da racionalidade normativa é uma crise da própria razão positivista, que se debate com a realidade humana sem encontrar soluções satisfatórias para seus problemas. São esses questionamentos que passamos a expor para melhor contextualizar, do ponto de vista epistemológico, o objeto das considerações que aqui havemos de expor sobre a normatividade e a validade das normas que compõem as legislações relativas aos Direitos Humanos.

A modernidade inaugurou e tem inaugurado uma série de questionamentos sobre a natureza da razão e de sua capacidade de explicar todos os fenômenos, tanto físicos quanto sociais, em contraposição à concepção clássica 
de cientificidade, para a qual, o conhecimento, como produto do espírito humano, obedeceria a uma série de postulados, engendrados em nossa consciência, submetidos e adaptados ao mundo exterior.

Verifica-se, dessa forma, a existência de dois aspectos nessa relação: um objetivo e um subjetivo, que se apresentam de forma indissociável de um racionalismo de característica dúplice, considerando a impossibilidade de se distinguir onde começa a percepção e quais são os seus contornos ao redor da existência noumenológica ${ }^{2}$ do objeto ${ }^{3}$.

A abordagem clássica do conceito de ciência leva, invariavelmente, a concepção de uma ciência cuja formação basilar, ou seja, cujo elemento fundante, carece de criticidade. Os fundamentos não são apreensíveis pela percepção científica e muito menos possuem rigor crítico porque seus fundamentos são podem ser questionados.

A matemática ilustra bem o que se ora afirma, ao lançar mão de elementos fundamentais, e previamente aceitos no bojo da geometria euclidiana: o ponto, a partir do qual se formam outros conceitos também basilares, mas desprovidos de criticidade, tais como, a reta e o plano, e que devem obedecer a comandos normativos, uma vez que os pontos devem estar, infinitamente, em seqüência para formar uma reta e, contrariamente, não estar em seqüência para viabilizar a formação de um plano qualquer.

Não deixam de ser essas assertivas comandos normativos, por vezes antagônicos $^{4}$. A ciência jurídica também padece desse problema. Quando nos

\footnotetext{
2 O noumenon (do grego voov́ $\mu \varepsilon v o v$, derivado de voć "eu penso") é utilizado com referência à possibilidade de conhecimento de um objeto ou evento sem que, para isso, sejam utilizados os sentidos. O campo de atuação do noumenon é a realidade mais intrínseca a que pode aspirar o conhecimento filosófico. O termo é bem conhecido da filosofica kantiana onde o noumenon é apresentado como uma impossível de ser conhecido pelo ser humano é a coisa-em-si (Ding an Sich), conforme a referência kantiana. O termo é utilizado, frequentemente, em contraposição a Fenêmeno que é o campo onde as coisas aparecem conforme referido na filosofia.

${ }^{3}$ Nesse sentido Gaston Bachelard reporta a existência de duas metafísicas que, didaticamente, seriam definidas como realista e racionalista, relacionadas ecleticamente."La science est um produit de l'esprit humain conforme aux lois de notre pensée et adpté au monde exterieur. Elle offre donc deux aspects, l'un subjetif, l'autre objetif, tous deux également necessaries, car il nous est aussi impossible de changer quoi que ce soit aux lois de notre esprit qu'à celles du monde. Étrange déclaration metaphisique qui peut aussi bien conduire à une sorte de rationalisme redoublé qui retrouverait, dans les lois du Monde, les lois de notre esprit, qu'à une realisme universal impossant l'invariabilité absolue $<<$ aux lois de notre esprit $>>$ concues comme une partie de lois de monde!"(Le nouvel esprit scientifique p.5-6)

${ }^{4} \mathrm{O}$ conceito da posse, analisado do ponto de vista de sua proteção jurídica, apresenta essa controvérsia. Segundo parte da doutrina a sua proteção deve ser administrada pela normatividade devido a ser esse o elemento pelo qual se externa a propriedade (conceito naturalístico), Essa mesma doutrina afasta a discussão do conceito de propriedade em sede de ação possessória. A única explicação que encontramos seria a de que, uma vez ingressado no mundo da racionalidade jurídica, a posse alça seu status de categoria (científico) - jurídica autônoma e enseja fenômenos jurídicos autônomos. O antagonismo argumentativo provocado pelo encontro dessas duas concepções informa o preceito jurídico ínsito no artigo 505 do Código Civil de 1916 in verbis "não obsta à manutenção, ou reintegração na posse, a alegação de domínio, ou de outro direito sobre a coisa. Não se deve, entretanto julgar a posse em favor daquele a quem evidentemente não pertencer o domínio.".
} 
referimos às normas jurídicas essas manifestações são adquirem o rótulo de antinomias jurídicas.

Essa natureza dúplice da possibilidade de conhecimento, enquanto fundada na natureza e na razão, ao passo em que beneficia a via diacrítica para a superação do seu princípio fundamental, desprovido de crítica, tem sido uma das causas de inúmeras confusões impressas na análise de diversos fenômenos físicos, sociológicos e jurídicos que, ora tomados pela acepção naturalística, ora pela via racional, resultam em assertivas, com caráter de cientificidade, mas que demonstram a necessidade de complementação, como é o caso da geometria nãoeuclidiana, da medida não-arquimediana, da mecânica não-newtoniana de Albert Einstein, da física não-maxwelliana de Bohr, da aritmética das operações nãocomutativas não-pitagóricas.

Tais resultados decorrem do fato de que o aspecto dúplice-metafísico informa o conceito de cientificidade, dessa forma, o mais ferrenho racionalista acaba por se ver obrigado a dar lugar ao conhecimento apreendido da realidade, e o mais fiel realista encontrar-se na via inexorável de ceder a algumas assertivas racionais para completar sua percepção de realidade. É nessa fenda entre o racional e o real que nos permitimos localizar os fenômenos jurídicos, de um lado há a norma positiva, racional, se impõe como um corte da realidade ou como a moldura kelseniana e do outro, há a realidade do fato que encerra o conflito submetido à jurisdição estatal.

É indiscutível que o conhecimento epistemológico ocidental sofreu grande influência do pensamento greco-latino, no que se refere às possibilidades do conhecimento. Essa perspectiva foi aprofundada e acrescida de fundamentação por outros filósofos da modernidade que, dando continuidade aos trabalhos de Platão e Aristóteles, estenderam a possibilidade de conhecimento para além do mundo inteligível, senão, ao menos, introduziram a fenomenologia como forma de aproximação metodológica para o conhecimento do noumenon. O Direito não ficou alheio a essa tendência e seguiu as diretrizes epistemológicas fundadas na teoria da ciência.

Kant, já no séc. XVII, advogava pela impossibilidade do conhecimento da "coisa em si". Para demonstrar suas teorias, o filósofo lança mão dos conceitos acerca do conhecimento a priori, que teria sua origem, ou fonte, na experiência empírica, sendo, por isso, relativo, e do conhecimento a posteriori, que para o 
filósofo, teria suas origem nos mecanismos de raciocínio do sujeito, possuindo, portanto, uma validade generalizante como característica peculiar. ${ }^{5}$

Tal método de conhecimento é antes, como o é todo método, uma forma de controle da validade do conjunto de proposições produzidas durante o ato que tem por pretensão o conhecimento de determinado objeto de estudo. Como qualquer outro método de conhecimento, essas teorias tendem a fornecer "sistemas de controle" e de aferição da validade das proposições que lhe são impostas, e se usadas com a devida parcimônia, tenderiam a informar maior ou menor validade à assertiva a ele submetida, em função do nível de aceitação do método.

O positivismo científico foi a corrente de pensamento que culminou com a crença nas possibilidades absolutas do conhecimento que, uma vez submetido ao método experimental-positivo, como forma de controle de seu conteúdo, atingiu o patamar de inquestionabilidade.

No entanto, com o advento de novos métodos de investigação, que necessitavam de maior precisão diante de uma realidade diversa, como era o caso da física infinitesimal e da física quântica, a razão viu-se constrangida diante da realidade, por não responder a contento às indagações mais simples. Nesse sentido, verificou-se a existência de uma fresta entre a racionalidade e a realidade, que a filosofia da ciência e a epistemologia moderna apressaram-se por tentar consertar.

No esteio dos ensinamentos do mestre francês Gaston Bachelard, é possível, também, concluir que, tanto o racionalismo, quanto o realismo científico estão abertos por uma via dialógica:

"A suivre ces verifications, on se concainc par exemple qu'en réalisme qui a rencontré le doute scientifique ne peut plus être de même espèce que le réalisme immédiat. On se convainc également qu`un rationalisme qui a corrigé des jugements a priori comme de fut le cas dans les nouvelles extensions de la géométrie, ne peut plus être un rationalisme fermé." 6

Concordamos que a modernidade traz, pela sua via colateral, a problemática do conhecimento científico frente a novas extensões de conhecimento, que demandam reflexão atenta e cuidadosa. No entanto, discordamos do grande pensador em relação à solução aventada para superar o impasse de integração no

\footnotetext{
${ }^{5}$ Dadurch unterscheidet Kant auch zwischen der Erkenntnis a priori und der Erkenntnis a posteriori. Die Erkenntnis a posteriori hat ihre Quelle in der Erfahrung und ist relativ. Die Erkenntnis a priori hat hingegen ihre Quelle im Denken des Subjekts und ist allgemeingültig und unbedingt notwendig.21 Die strenge Allgemeinheit und Allgemeingültigkeit sind bei Kant das sichere Kennzeichen der Erkenntnis a priori. (SAKYKHAN, Voladet, 2000, p.13)

${ }^{6}$ BACHELARD, Gaston, Le Nouvel Esprit Scientifique, p-7
} 
campo do conhecimento científico que, para ele, residiria no campo da filosofia, que deve submeter a sua elocução reflexiva a serviço do conhecimento científico.

Embora não seja o objetivo dessas considerações estabelecer as bases de uma nova metodologia científica para o estudo das ciências do espírito, é possível, a nosso ver, promover a superação desse hibridismo racional sem recorrer à uma terceira metafísica.

Contudo, por inadequação conjuntural da matéria, que é atinente à filosofia da ciência, e por conta da sua incapacidade de atender aos anseios de formulação de uma teoria cientifica autorreflexiva, em desconformidade com 0 LeitMotif do presente trabalho, essa nova visão epistemológica será abordada de forma lateral, na medida em que forem suscitados elementos categóricos, com vistas a favorecer a idéia de uma ordem justificada e universal de direitos do homem.

Pode-se adiantar que é a via dialógica entre a razão e a realidade, que pode ser operada por meio de uma prática discursiva sobre os pressupostos da igualdade e da liberdade, como ponto de partida para a formulação de uma razão ou de uma validade normativa universal. Nesse sentido assevera Miroslav Milovis:

"A validade normativa, devido a isso, somente se alcança quando se puder
obter ou possivelmente obter - eis o caráter ideal - o consenso de todos
possíveis participantes implicados nas deliberações racionais. Todo
conteúdo normativo possui, dessa forma, uma dependência com os
discursos práticos. Nesse aspecto, o princípio U, faz com que se supere a
lacura existente entre o universal e o particular""

É possível ter entender que o Direito sofreu de todos as esquizofrenias de que vem sofrendo a teoria da ciência, principalmente porque as ciências jurídicas se assentaram sobre os pressupostos científicos do positivismo. A crise de realidade e de validade enfrentada pelo Direito frente à sua cientificidade é um importante ponto de partida para que se possam apresentar novos métodos de validação do discurso jurídico que não tenham, necessariamente, que se fundamentar na positivação da norma, desconsiderados os fundamentos que lhe devem, necessariamente, originar.

\footnotetext{
${ }^{7}$ MILOVIC, Miroslav. Filosofia da Comunicação. Para uma Crítica da Modernidade op cit, p267 Racionalidade Jurídica e Validade Normativa op cit pág 211
} 


\subsection{Positivismo jurídico e linguagem científica}

A disposição desse subtópico, inserto na parte dedicada ao tratamento dos temas Direito e ciência, não tem outra intenção senão a de abrir um parêntese entre as considerações que até aqui foram tecidas sobre a filosofia da ciência, e formular questionamentos acerca dos impactos que o pensamento científico produziu no pensamento jurídico, mormente aqueles relativos ao translado de termos científicos do campo das ciências experimentais, para a descrição e instrumentalização de institutos de natureza jurídica.

Estamos habituados, quando no manejo de códigos, jurisprudência e leis, a nos confrontar com termos como sujeito, objeto, existência, validade etc. Esses instrumentos de compreensão e de operacionalização do Direito como ciência se passam, muitas vezes, por termos integrantes da linguagem jurídica, sem que tenhamos jamais questionado qual a sua natureza e função no cenário que se estabelece para a composição do conflito.

A partir dessa constatação, é possível inferir que existe uma via dialógica entre as ciências da natureza e as ciências do espírito, das quais fazem parte as ciências jurídicas, e que pode ser suscitada com vistas a encontrar novas saídas metodológicas para as ciências do Direito, a partir de paradigmas criados e fundados no método experimental das ciências exatas, mormente sobre as suas razões epistemológicas e práticas.

No entanto, a partir das exposições modernas sobre a natureza do sujeito, do objeto e sobre a própria relação entre eles no âmbito da observação científica, seria interessante tecer algumas considerações sobre os problemas filosóficos e científicos que tem sido levantados e sobre a existência ou não implicações dessas indagações no campo das ciências jurídicas.

Sabe-se que o conceito de sujeito e objeto tem recebido um novo significado do ponto de vista das ciências da natureza, mas até que ponto essa conceituação ou nova caracterização da categoria pode afetar a nossa compreensão de seu papel no discurso jurídico? Esse questionamento não tem por objetivo obter respostas peremptórias, senão trazer ao debate os reais impactos do discurso científico sobre o discurso jurídico, sem, no entanto, aprofundar nessas divagações, que, são de fato, matéria para outras considerações. 
O ponto de partida dessas elucubrações poderia ser o fenômeno da generalização, por dois motivos. O primeiro diz respeito ao próprio contexto em que as ciências vêm se modernizando, em razão das especificações de seus objetos de estudos que, muitas vezes, passam a não atender ou responder, da forma esperada, aos princípios generalizantes desenvolvidos no âmbito da ciência clássica, necessitando, às vezes, que se crie uma regra ou método para cada caso, o Direito também tem sofrido com esse fenômeno, que se encontra bastante perceptível no estudo dos microssistemas de Direito.

O segundo motivo está no distanciamento que esses microssistemas aparentemente promovem em relação à ciência generalizadora. Esse é, justamente, o ponto falho sobre o qual qualquer ciência com pretensão de verdade universal esbarra, principalmente quando os objetos dessas ciências começam a se diferenciar em si mesmo, como ocorreu na física, em que o houve diferenciação entre a macro e a microfísica. O próprio Heisenberg tentou encontrar uma equação universal com a qual desejava expressar toda a física e esbarrou em novas perspectivas metodológicas, que não eram contrárias à abordagem científica generalizante, mas que eram complementares ao método científico tradicional e, portanto, exigiam uma nova metodologia para acoplar-se cognitivamente ao sistema de conhecimento da física moderna. H. Bondi (1997) menciona o fato, como exemplo de um problema básico da generalização na ciência:

\begin{abstract}
"Minha opinião é que qualquer teoria que pretenda explicar tudo, falha exatamente neste ponto. Ela seria uma teoria inutilmente rígida, já que não teria espaço para absolver novas descobertas, não teria como acrescentarIhe novidades. É verdade que novas descobertas poderiam transtornar algumas teorias e até invalidá-las completamente, conseqüentemente, deveríamos no mínimo, estruturar nossas teorias de modo que as novas descobertas não chegassem a sobrepujá-las, e para isso deveríamos mantê-las suficientemente abertas."
\end{abstract}

O Direito tem sofrido com esse problema de incompatibilidade entre os microssistemas e a teoria generalizante, embora, dada sua natureza positivista, observe-se a formulação de princípios integradores de fenômenos jurídicos que, por vezes, estão a compor sistemas, aparentemente antitéticos, a exemplo da ponderação de valores, que fornece uma via interpretativa para que as normas não venham a desmoronar e levem com elas todo o sistema. No mesmo esteio das

\footnotetext{
${ }^{8}$ H.Bondi. Conjectura e Mito da física. Trat de Paulo César Morais -Brasília: Editora Universidade de Brasília, $2^{\circ}$ Ed., 199757 p.
} 
conclusões de H.Bondi, no Direito as teorias não estão abertas, pois a lei possui, no positivismo, um fator ontológico sob o qual não recai qualquer criticidade.

Na medida em que vão surgindo novos fenômenos sociais, vai surgindo a necessidade da formatação de novos conceitos de abordagem com vistas a dar uma satisfação razoável ao problema ou conflito que se deseja resolver. E não fora isso, que os códigos, que, no campo do Direito, seriam o que um conjunto de equações é para a termodinâmica, vão dando lugar aos microssistemas ${ }^{9}$ que, guardadas as devidas proporções, não são outra coisa senão dispositivos customizados para a resolução de problemas específicos, como o é a física relativística e a geometria do motorista de táxi.

O ponto é saber se é possível adaptar a linguagem e os conceitos que estão por trás dessa última para criar uma formulação diferente de Direitos Fundamentais, que, embora possuam uma tendência a se inscrever nos mesmos conteúdos já conhecidos possam trazer em seu bojo um conteúdo que se possa legitimar e conferir pretensões de universalidade.

A linguagem positivista não favorece tal acepção jurídica, porque o objeto, ou melhor, o conceito de sujeito e objeto não fornecem bases para a crítica e não suportam críticas ao seu próprio fundamento. No positivismo a norma está ontologicamente comprometida com sistema de Direito, na medida em que ela é o que deve ser definido, encontrado e estudado, com todos os olhos voltados à reflexão sobre a sua interpretação. No entanto, essa interpretação está restrita à própria norma e seus fundamentos não comportam qualquer crítica.

Essa base acrítica, sob a qual se inscreve a norma positivada, não se presta a explicar a existência de um Direito universal que trate de Direitos Humanos. A afirmação é de fácil defesa sob a argumentação de que a validade da norma positiva pode não suportar os ataques e a argumentação de todos aqueles que devem ser regulados por ela, por não fazer parte, ou melhor, por não ser produto de uma prátrica discurssiva aberta, igual e livre entre todos aqueles a ela submetidos.

A partir dessas poucas considerações, começamos a apontar para a solução normativa que entendemos acertada para a legitimação e fundamentação

\footnotetext{
${ }^{9} \mathrm{O}$ volume atual de leis, decretos, tratados, supera toda a possibilidade de conhecimento do cidadão comum. O Código já não abrange todas as situações, a legislação especial já não é uma mera ratificação de axiomas codificados. Ao contrário, muitas vezes pretende derrogá-los. È difícil estabelecer uma ordem, e mais ainda manter princípios irrefutáveis de base racional. LORENZETTI, Ricardo Luiz. Teoria da Decisão Judicial: Fundamentos de Direito- São Paulo. Editora Revista dos Tribunais.2009 p. 43.
} 
crítica de uma ordem de Direitos Humanos que possa sustentar-se criticamente sobre seus fundamentos e atingir uma pretensão de validade que se possa nomear de universal.

\subsection{O problema do positivismo científico nas ciências exatas atinge o Direito?}

Ao final do tópico anterior concluímos que a ciência do Direito também padece dos mesmos problemas epistemológicos das ciências naturais, em relação aos fenômenos jurídico-sociais, que possuem comportamento diverso e plural, para o qual, muitas vezes, a abordagem meramente positivista, a partir da estrita subsunção do fato à letra da lei, não é suficiente para operacionalizá-lo, incluí-lo no sistema jurídico e conferir-lhe a funcionalidade desejada, que é a resolução do conflito, com base na realidade particular e voltado para essa particularidade. Da mesma forma que não ocorre no método experimental que, ao se confrontar com uma nova realidade, pode ser que não Ihe consiga explicar, senão a partir da confecção de um novo conjunto metodológico, como ficou acima explicitado.

O impacto dos problemas filosóficos do positivismo sobre a funcionalidade da ciência jurídica é, questão constantemente, revirada pelos pensadores do Direito, mormente nos aspectos relativos à validade da norma jurídica e dos métodos utilizados para a confecção da decisão judicial. Basta lançar um olhar sobre os problemas suscitados pela racionalidade jurídica e a validade das normas emanadas pelo Direito, para se constatar que a disposição epistemológica do mesmo, baseada no positivismo, gerou uma matriz jurídico-positiva causadora de diversos problemas tanto de ordem, quanto científica. Esse problema toma contornos nítidos na eterna dicotomia sob a qual se debate, desesperadamente, o operador do Direito, entre fazer aplicar a lei em detrimento da justiça ou favorecer a justiça ao arrepio da lei: essa fresta entre o ideal e o real, que não possui uma via dialógica no positivismo, é um dos principais problemas epistemológicos dessa corrente de pensamento, e como tal, se reflete no Direito, como expusemos acima.

É tentador seguir a diretrizes que essas considerações vão, as vezes per se, imprimindo às discussões que ora se aventam, e que nos levam a discutir e a levantar todo um conjunto de problemas que o Direito, enquanto ciência positiva, fornece, face às demandas da sociedade por uma solução real aos conflitos que se 
formulam, haja vista o padecimento de um problema metodológico herdado da sua própria matriz epistemológica.

O Direito do nosso tempo não padece de problemas por ser Direito ou por ser ciência, mas sim por ser positivo, e, conseqüentemente, padecer de todos os problemas teóricos e metodológicos de que padece o positivismo, a começar pela impropriedade da norma positiva para suportar elementos críticos que não façam parte de seu próprio fundamento.

Se, como concluímos nas passagens anteriores, o positivismo jurídico sofre dos mesmos problemas metodológicos que outros ramos do conhecimento, seria, então, possível lançar mão de paradigmas epistemológicos dos quais se valeram as ciências exatas para resolver seus problemas em determinados campos do conhecimento? A nossa resposta é afirmativa, pois, quando se cogita da utilização do paradigma de raciocínio de uma ciência em outra, não se está falando de aplicação pura da metodologia, mas sim da aplicação do mesmo raciocínio para enfrentar problemas que são, epistemologicamente, ou filosoficamente, equivalentes.

É o que, acanhadamente, procuraremos viabilizar nessas breves considerações, a partir das concepções básicas da teoria da relatividade em conjunto com a teoria habermasiana da razão comunicativa, procurando encontrar uma metodologia capaz de validar uma ordem racionalmente fundada e com pretensão de universalidade sem perder a capacidade crítica na formulação e promulgação de conteúdos afetos aos Direitos Humanos.

\subsection{0 que é relatividade?}

A Teoria Especial da Relatividade foi formulada em 1905 e faz parte de um conjunto de duas teorias: a Teoria da Relatividade Restrita e a Teoria da Relatividade Geral, que compõem a Teoria da Relatividade.

Essa teoria substituiu os conceitos de tempo na teoria de Isaac Newton pela idéia de tempo como entidade geométrica. Com isso, o tempo passa a ser uma unidade de medida. A referida teoria está assentada sobre dois pressupostos epistemológicos:

1. A física relativista abandona a idéia de observador inercial absoluto para substituí-la pela idéia de observadores inerciais 
relativos. Para a Teoria da Relatividade Restrita as leis da física são iguais para todos os observadores que estejam em movimento uniforme, um em relação ao outro.

2. A velocidade da luz no vácuo é a mesma para todos os observadores, independentemente de seu movimento relativo ou do movimento da fonte luminosa.

Vista sob o prisma de seus pressupostos, sem qualquer explicação adicional, a Teoria da Relatividade parece confirmar o que afirma o senso comum sobre o significado do termo relatividade.

Nesse ponto, permite-se questionar a finalidade de, a essa altura do trabalho, estar-se introduzindo uma teoria que é julgada de extrema complexidade, e qual é a sua pertinência com os Direitos Humanos. Após serem explicitadas algumas características matemáticas no bojo do conceito de Relatividade, buscaremos envolver esses conceitos em considerações acerca da possibilidade de universalização dos Direitos Humanos com arrimo na idéia de universalidade relativa e na Teoria da Razão Comunicativa. Para tanto, passamos à explicação do que seja o fator $k$, na Teoria da Relatividade.

Einstein ao se manifestar sobre a Relatividade Restrita afirmou que

"Ninguém possui idoneidade para fazer afirmações a respeito do
espaço absoluto ou do movimento absoluto. São meras formas do
espírito, construções mentais que não podem ser embasadas na
experiência. Todos os princípios da mecânica resultam dos nossos
conhecimentos empíricos a respeito das posições e dos movimentos
relativos dos corpos."

A afirmação do físico remete à profundidade filosófica e amplo significado da Teoria Relatividade para a teoria da ciência. Para as considerações aqui tecidas, nos valemos da assertiva do físico ao negar a possibilidade de se aceitar a afirmação sobre um tempo e um espaço absolutos. Podemos posicionar a nossa afirmação sobre a relatividade dos Direitos Humanos como um contraponto à afirmação de que tais direitos são absolutos, mesmo que se apresentem em sociedades desenvolvidas sobre suportes morais, éticos, jurídicos e antropológicos diferentes.

No entanto, a maneira mais simples de se explicar a teoria da relatividade é do ponto de vista prático, pois, filosoficamente, seríamos consumidos por páginas e mais páginas de elucubrações, infrutíferas ao final. Portanto, como não é nosso objetivo esmiuçar a filosofia das ciências e nem o fundamento matemático da teoria, 
mas apenas introduzir o leitor nos conhecimentos básicos sobre o conceito da teoria da relatividade, passemos à explicação do anunciado fator $k$, para que se entenda qual o papel de seu fundamento filosófico na confecção das bases e da metodologia para validação e justificativa de uma ordem normativa de Direitos Humanos, com capacidade de ser universal, sem perder a possibilidade de submissão de seus pressupostos à crítica verdadeiramente democrática.

O fator $k$ é, em verdade, uma derivação do princípio da Relatividade, cuja aplicação pode tornar mais clara suas conseqüências. É desse modo que nos desviamos das complexas ilações, tanto matemáticas quanto filosóficas, e procuramos esclarecer, a partir da natureza dessa constante, que o fator $k$, é um elemento relacional entre dois elementos que se relativizam, podendo adquirir uma característica de imutabilidade e de universalidade, com base em pressupostos definidos.

Mais à frente, ao serem introduzidas considerações acerca da possibilidade de relativização dos Direitos Humanos, serão somados ao argumento, outra teoria, que, se lograrmos êxito nessa exposição, demonstraremos estar assentada sobre os mesmos pressupostos filosóficos que a Teoria da Relatividade, e, que ambas, dão suporte à possibilidade de formatação de uma ordem universal de Direitos do homem, baseados em pressupostos passíveis de serem criticados.

A idéia básica do fator $k$ repousa sobre a consideração de um conjunto de observadores inerciais que se movem ao longo de uma linha reta, para facilitar a compreensão, abre-se mão da tridimencionalidade especial, para representá-lo em duas dimensões, num diagrama espaço/tempo (fig.1), sendo que a vertical representa alguma, ou melhor, qualquer medida de tempo, e a horizontal alguma medida e espaço. Como afirma o Bondi ${ }^{10}$, os diagramas não têm a finalidade de ser precisos, servindo apenas como uma indicação grosseira do que se fala, em que lugar e quando. 


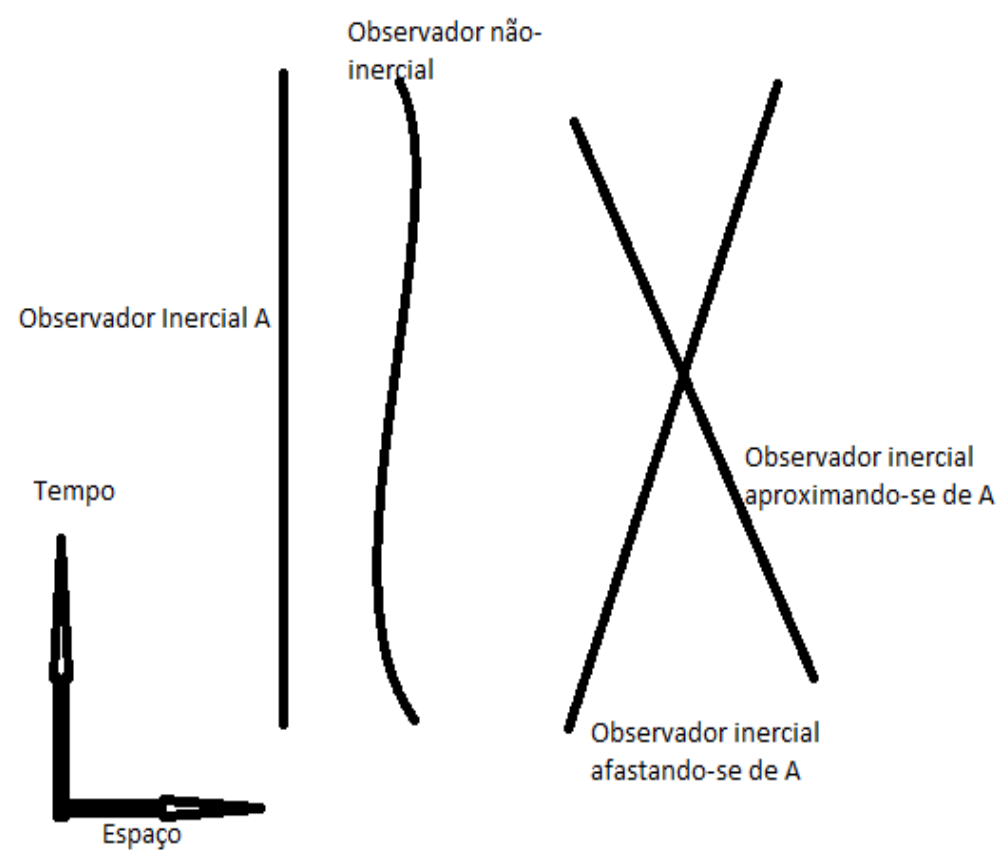

Figura 1

O observador "A" é indicado pelo eixo do tempo, portanto está ele sempre na origem das coordenadas espaciais. Conforme os diagramas acima, qualquer observador inercial, cuja posição não coincida com "A", move-se, em relação a "A" com velocidade constante, podendo, portanto, ser representado, presumivelmente, por outra linha reta. Essas constatações, ao contrário do que possa parecer, agasalham uma série de complicadas imbricações, como afirma o próprio físico:

"Gostaria de realçar que uma quantidade enorme de suposições está intrinsecamente ligada a um diagrama desta espécie, embora boa parte dela se relacione apenas com a representação esquemática e não com a teoria que forma a base."

Outro pressuposto é que os observadores inerciais estão dotados de relógios idênticos ${ }^{11}$. Suponha-se, então que o observador "A" emita dois sinais luminosos em sucessão, sendo que, pelo seu relógio, haja um intervalo de tempo T entre esses dois sinais pelo observador "B".

${ }^{11}$ É de fundamental importância notar que, mesmo a teoria da relatividade é dotada de pressupostos que, se não obedecidos inviabilizam a conclusão, a equivalência do termo "pressuposto não coincide com o conceito de pressupostos a que nos referimos no direito, para os efeitos de nossas considerações será ele traduzido, mais à frente, pelo termo proposição muito utilizado na lógica e na teoria da linguagem. e com o qual ficaremos mais confortáveis para sair do universo da física e introduzir os conceitos-chave para nossas considerações, que, em muito se aproximam da filosofia da linguagem, que é a base do pensamento habermasiano para a teoria da Ação Comunicativa. 


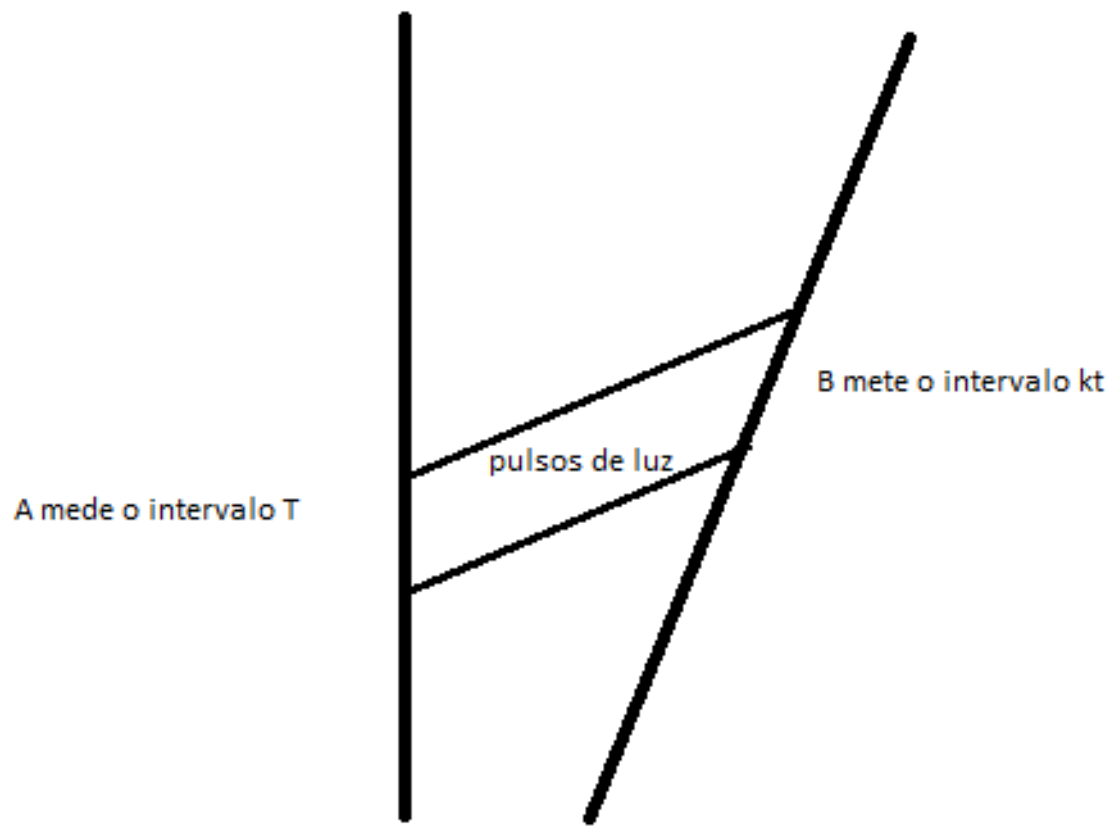

Figura 2

Pode-se, então, chamar de "kT" o intervalo entre a recepção dos dois sinais luminosos marcados no relógio do observador inercial "B". Ficando admitido que "A" e "B" são observadores inerciais, então "k" seria uma constante de tempo independente de "T".

A importância dessa conclusão é explicitada pelo Professor Bondi (1997: 24), ao afirmar que :

Percebe-se que essa é uma hipótese de grande importância, já que a definição de observadores inerciais decorre da primeira lei de Newton, e, por isso, é dinâmica,. A definição de estado de movimento no qual a razão " $k$ " entre o intervalo de recepção do sinal e o intervalo de transmissão do mesmo é constante em tempo, é uma definição de algo bastante diferentes. Pode-se chamada de geometria ou de cronométrica ou de qualquer outra coisa. Dessa forma admito que um movimento dinamicamente inercial corresponde ao movimento com $k$ cronometricamente constante. Creio que dentre todas as suposições intrinsecamente ligadas à construção de tais diagramas, a única realmente relevante para o desenvolvimento da teoria ( e não apenas para a representação pictórica) é a suposição da equivalência entre a dinâmica, no sentido da lei da inércia, e a cronométrica, no sentido de $k$ ser independente do tempo de emissão.(grifo nosso) ${ }^{12}$

A primeira conclusão que se deve depreender e que será muito importante para nossas considerações é a de que, embora a natureza dos dois elementos a

12 H.Bondi. ibidem, p. 25. 
que se referem as retas seja dinâmica, ou seja, a referência seja feita com base nos movimentos que ambos, "A" e "B" perfazem, o resultado demonstra a existência de um fator (o fator $k$ ), que possui natureza bastante diferente dos sujeitos do movimento. Isso demonstra que é possível inferir, por meio de um fator relacional, que nesse caso vincula os observadores inerciais " $A$ " e "B", a probabilidade da existência de um fator racional essencial que seja universal, sem, no entanto perder o contato relacional com as naturezas dos objetos a que se vincula.

Transplantadas essas considerações para um plano sócio-antropológico, em que "A" e "B" fossem grupos sociais distintos, poderíamos, então, tentar firmar um fator "k" universal que mantivesse relação com ambas as sociedades sem, no entanto, estar condicionado à natureza ou qualquer fundamento de nenhuma delas. É esse raciocínio que tentaremos formular nas considerações que ora se seguem.

Acentue-se que as conseqüências matemáticas ou físicas no exemplo dado, para nossas considerações, tem menos importância que o fator que relaciona os dois observadores, que, como será demonstrado ao longo desse tópico, não será modificado, quaisquer que sejam os observadores inerciais. Nosso paralelo com o Direito aponta para a viabilidade da existência de um ponto em comum entre as sociedades, qualquer que seja sua matriz cultural, apto a ser o ponto fundante de um discurso universal para os Direitos Humanos.

A fim de concluir as observações que, até aqui, tecemos sobre a teoria, vamos supor, agora, que "B" emita pulsos de luz, em intervalos iguais a "T", medidos pelo seu próprio relógio e que esses pulsos são recebidos por "A", baseados nos mesmos pressupostos anteriores, em intervalos iguais a " $k \mathrm{~T}$ ", uma vez que, pela relatividade há uma presunção de equivalência entre eles. O importante é que só há equivalência entre " $A$ " $e$ " $B$ " porque o fator $k$ é assumido como constante em todas as direções, esperando-se então a mesma conclusão de "B" em relação a "A", como de "A" em relação a "B".

É dessa bidirecionalidade, ou seja, do comportamento igual de um em relação ao outro, que podemos retirar algumas bases paradigmáticas para tentar formular condições em que os direitos do homem, formulados no bojo de sociedades distintas possam ser capazes de comportar, por meio de um fator que os relacione, um conteúdo universal e constante, que possa servir de base normativa para a proclamação de uma ordem universal de Direitos Humanos. 
Antes, porém, para não dar lugar a equívocos, articularemos algumas considerações sobre as diferenças existentes entre o termo Relatividade e Relativismo, que, se não tratados de formas distintas, podem ensejar conclusões antitéticas, principalmente para aqueles que estão não familiarizados com a teoria habermasiana, mormente à possibilidade de uma Teoria da Ação Comunicativa, cujas pretensões de universalidades podem conflitar com os conceitos conhecidos no bojo das ciências humanas sob o título do Relativismo.

\subsubsection{Relatividade e Relativismo}

Antes de desferir qualquer incursão acerca da aplicação dos conceitos que pairam sobre o significado do que seria Relatividade para a ciência jurídica, tal qual se encontra hoje, é necessário que se estabeleçam diferenciações entre o sentido que pretende-se conferir ao conceito de relatividade, aplicado aos Direitos Humanos, do conceito de Relativismo, há muito conhecido e que tem, no âmbito das ciências humanas, um conceito que, embora carecedor de definição exata, confere a essa teoria características peculiares.

Primeiramente, é importante acentuar que a principal diferença residente entre o conceito de Relatividade e Relativismo está na origem de cada conceito. O conceito de Relatividade foi desenvolvido para as ciências naturais, mormente no bojo da física moderna, e tinha por objetivo a suplantação e suplementação de um modelo de natureza estático que fora impresso pela física de vertente newtoniana ${ }^{13}$, estando, portanto, em perfeita conformidade com o método físico experimental.

O Relativismo, por sua vez, tem origem na filosofia. O termo foi concebido na teoria do conhecimento formulada pelos sofistas, segundo a qual o conhecimento e os valores não são absolutos, possuindo sua validade condicionada a

\footnotetext{
13 A mecânca clássica é composta por um conjunto de postulados forjados, no início do século XX, para descrever um sistema físico-matemático iniciado por Isaac Newton em conjunto com a filosofia natural. Os postulados de Newton partiram de um pressuposto de que poderiam existir leis universais para explicar todo o universo. Esse, por muito tempo, passou a ser o objetivo dos cientistas, físicos e filósofos. No entanto, a física relativística e a mecânica quântica têm demonstrado que a possibilidade de generalização da física newtoniana não atendia a muitos outros setores da natureza. É o que ficou demonstrado quando o cientista se deparou com grandes ou com pequenas medidas tendentes ao infinito.
} 
determinados fatores de referência ${ }^{14}$. O relativismo, enquanto conceito filosófico, se aninhou nas teorias das ciências sociais no início do século $X X$, e se transformou em um dos fundamentos essenciais do multiculturalismo, que apresentamos acima como ponto de referência para a inauguração da possibilidade para a criação de uma saída metodológica para a formulação crítica de conteúdos afetos aos direitos humanos.

É inegável o valor da teoria no bojo das considerações que ora tecemos, por ter apontado a possibilidade de uma discussão dos fundamentos que conferem a validade do conteúdo que compõe o discurso voltado aos direitos do homem, sobre perspectiva diversa daquela que Ihe conferia as pretensões de universalidade sob o prisma da cultura ocidental européia. Não se pode olvidar, no entanto, as críticas tecidas ao multiculturalismo e que, por assim dizer, podem ser estendidas, também, ao Relativismo.

Nos termos que compreendemos o estudo sobre direitos humanos, Relativismo e Relatividade são conceitos diferentes. O objeto desse trabalho, visto pela óptica do Relativismo, pode levar a conclusões diametralmente opostas ao que se pretende afirmar, visto que são teorias diferentes e, para nossos objetivos, incompatíveis, mesmo que ambas forneçam certa base crítica sobre o conteúdo em apreço.

As soluções produzidas pela incidência de uma ou outra teoria são antitéticas, como procuraremos mostrar mais a frente em nossas conclusões, mesmo que de forma perfunctória. A afirmação e confirmação da diferença se devem ao fato de que pertencem esses dois conceitos a correntes epistemológicas distintas: o Relativismo, possui vertente ética e cultural, e embora seja capaz de articular a formulação de críticas sobre as pretensões de universalidade em que se incluem as críticas à própria universalidade "declarada" dos direitos do homem, não fornece a chave, nem sequer aponta, para a possibilidade de uma ordem universal de Direitos Humanos.

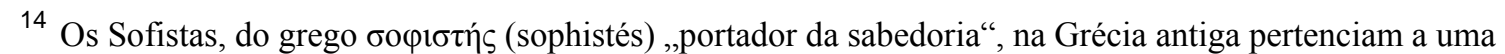
categoria de filósofos especializados no uso de ferramentas filosóficas e da retórica para o ensinamento da arete, da virtude.
} 
Para essa teoria, qualquer tentativa de estabelecer direitos de validade universal sempre culminaria com o desrespeito às idiossincrasias de determinados grupos sociais, sendo, portanto, atentatória aos princípios básicos estabelecidos pelo conjunto de valores formulados por uma determinada cultura. Portanto, com base nessa corrente de pensamento, não é possível a formulação de uma ordem universal de direitos que possa ser respeitada por todos os homens, sem que esses mesmos homens tenham que renunciar às características intrínsecas de seus grupos sociais, sendo, portanto, qualquer ordem universal de direitos, uma imposição inaceitável violadora da dignidade do grupo que deve ela mesma garantir.

Por outro lado o conceito de Relatividade, emprestado pela física relativa, ao contrário do que se faz acreditar o senso comum, pode ser definido a partir do abandono da idéia de tempo universal, e de retorno à idéia elementar de que qualquer quantidade física somente se define com relação ao método utilizado para defini-la ${ }^{15}$. Há a noção de relação conjuntiva entre dois sistemas postos em observação, nisso, a Relatividade de opõe, cabalmente, ao Relativismo, cujos objetos relacionados são apostos de forma disjuntiva, sendo ignorada sua relação como fator preponderante e generalizante para a formulação de um fator comum de base racional entre eles.

No Relativismo, os fenômenos são considerados em si mesmos, há um estranhamento, uma negação do outro enquanto que, na teoria da Relatividade, há uma relação de inclusão do fenômeno que somente pode ser identificado em relação ao outro, que lhe é aposto e vice-versa.

\subsection{A relativização dos direitos na linguagem jurídica moderna}

Antes de discorrer sobre a relativização de direitos, mormente aqueles relativos aos Direitos Humanos, é interessante afastar também, o sentido que a doutrina tem conferido ao termo relatividade ao referir-se aos direitos inscritos no âmbito de valência dos Direitos Humanos.

A doutrina constitucional moderna, quando faz menção à relativização de um determinado direito, o faz sob o pressuposto de que esse Direito perde algo em sua substância. É isso que podemos depreender de referências como a do Professor Celso Ribeiro de Bastos:

\footnotetext{
${ }^{15}$ É nesse sentido que se deve definir o termo Relatividade, quanto às medidas utilizadas sobre o objeto de Estudo e não quanto à possibilidade de mudança do conteúdo essencial desse objeto.
} 
"As Constituições modernas falam em função social da propriedade com isso querendo significar que o direito só existe na medida em que esteja a desempenhar uma função. Houve, portanto, o que se pode chamar uma relativização de direitos que os condiciona a um uso normal e não abusivo. Mas maiores alterações ocorreram." 16

As referências à relatividade, principalmente no campo da dogmática constitucional, que, só recentemente, vem se libertando da lente positivista, tende a conferir ao conceito de relatividade uma idéia de enfraquecimento da essência de um Direito, que somente possui significado se funcionalizado em um sistema. $\mathrm{O}$ conceito de relatividade está, dessa forma, ligado a um potencial enfraquecimento do sistema, conferindo um significado, muitas vezes, pejorativo ao conceito de relatividade jurídica. Nesse sentido Celso Ribeiro Bastos afirma que:

\begin{abstract}
"Cada geração deve ser artífice de seu próprio destino; e) argumento de Biscaretti: admite-se que um Estado pode decidir sua própria extinção; "não se compreende porque o Estado não poderia, então, modificar igualmente em forma substancial seu próprio ordenamento supremo, ou seja, sua própria Constituição, ainda atuando sempre no âmbito do direito vigente". Por esses motivos Vanossi conclui pela inutilidade e relatividade jurídica das cláusulas pétreas expressas. Sua virtualidade jurídica se reduz a zero nas seguintes hipóteses: a) a cláusula proibitiva é desrespeitada, e a reforma do conteúdo proibido torna-se eficaz, com vigência perante os órgãos do Estado e acatamento comunitário; b) superação revolucionária de toda a Constituição, em que desaparece a própria norma proibitiva; c) derrogação da norma constitucional que estabelece a proibição, mediante procedimento regular, e ulterior modificação do conteúdo proibido." ${ }^{17}$
\end{abstract}

Em relação aos direitos do homem, é possível encontrar, na doutrina, referências à relatividade desses direitos, mas aqui, mais uma vez, constata-se que a referência se faz dentro de uma argumentação que favorece o enfraquecimento do conteúdo essencial do direito fundamental, por achá-lo incompatível com o conteúdo essencial desses direitos. Assim, mais uma vez, a óptica jurídico-positiva esbarra no conceito de relatividade com absoluta impropriedade epistemológica, uma vez que a norma positiva em seu conteúdo e a formação ontológica não aceitam uma medida, por dizer, por mais racional ou racionalista que seja, que não lhe seja advinda de seu próprio conteúdo essencial.

Virgílio Afonso da Silva advoga pela existência de um conteúdo essencial relativo dos direitos fundamentais admitindo ele que "a própria idéia de conteúdo essencial leva intuitivamente à crença de que ele só pode ser absoluto e com

16 BASTOS, Celso Ribeiro. Curso de direito constitucional. Saraiva. 20. ed. São Paulo Saraiva, 1999.

17 Idem, ibidem. 
contornos bem definidos" 18 . O Professor afirma, ainda, que o ponto central de toda a teoria relativa seria a negação de um conteúdo essencial como um âmbito de contornos fixos e definíveis a priori para cada direito fundamental. O conceito introduzido aqui é, intrinsecamente, disjuntivo, a exemplo do que expusemos alhures, quando nos referimos ao relativismo, e conforme podemos constatar pelas afirmações do próprio estudioso, essa teoria não comporta uma conjunção de Direitos, mas, como relativismo, induz a um embate entre os seus conteúdos essenciais:

"Segundo os adeptos de um conteúdo essencial relativo, a definição do que é essencial - e, portanto, a ser protegido - depende das condições fática e das colisões (grifo nosso) entre diversos direitos e interesses no caso concreto. Isso significa, sobretudo, que o conteúdo essencial de um direito não é sempre o mesmo, e poderá variar de situação para situação, dependendo dos direitos envolvidos em cada caso." 19

Desse ponto, e conhecendo o sentido que a doutrina jurídica tem conferido ao conceito de Relatividade de direitos, passamos à tentativa de conferir um conceito reformulado, baseado no paradigma da relatividade física que, como dissemos anteriormente, não possui característica disjuntiva, e sim conjuntiva de direitos.

Em outras palavras, enquanto o Relativismo, ao relacionar Direitos, tende a tocar em seu conteúdo essencial, enfraquecendo-o, conforme ficou demonstrado acima, a Relatividade procura a possibilidade de formatação de uma razão universal que mantenha a integridade dos conteúdos essenciais dos agentes ou Direitos envolvidos.

\subsubsection{O significado de se relativizar direitos}

Mais adiante, buscaremos demonstrar que essa perspectiva de inclusão, ou de conjunção relativa, no que diz respeito a direitos, é de grande valor para formulação de um conjunto de Direitos Humanos que possam povoar a pretensão de universalidade requerida sem, no entanto, perder-se a possibilidade de sujeição crítica de seu fundamento.

\footnotetext{
${ }^{18}$ SILVA, Virgílio Afonso da. Direitos Fundamentais, conteúdo essencial, restrições e eficácia. Malheiros Editores. São Paulo:2009.

19 Idem, ibidem.
} 
Essas considerações tencionam descortinar o essencialismo proclamado na estrutura normativa e nas declarações que tratam dos Direitos Humanos e, utilizando-se do paradigma epistemológico, que tornou possível a formulação da teoria da Relatividade, demonstrar que a idéia de Direitos Humanos com caráter absoluto e universal, fundado na matriz cultural de viés ocidental, sucumbe, necessariamente, à formulação de um conjunto de direitos que, tendo por matriz metodológica, ou como forma de controle normativo-discursivo, o consenso baseado na igualdade e na liberdade, não são capazes de informar e conformar uma ordem de Direitos Humanos sobre uma matriz crítica, sem, no entanto, alterar ou vulnerar os aspectos idiossincráticos dos grupos participantes da ordem normativa fundada nesses direitos.

Sob os mesmos argumentos que causaram a superação do conceito de tempo absoluto na física moderna, diante da idéia de simultaneidade, com o abandono da existência do significado do absoluto impresso pelo relógio, é possível experienciar a superação de um conceito de Direitos Humanos de conteúdo estanque, diante da idéia de co-existência entre os povos. Da mesmo forma que a idéia de simultaneidade teve de ser trabalhada naquela teoria, para obedecer a determinados pressupostos fáticos, aqui, também, há que se fazer notar que a coexistência, que será nosso elemento paragonado para a simultaneidade, também deverá obedecer a determinados pressupostos que mais a frente passaremos a expor, mas que, de antemão, pode-se adiantar que fazem parte do conjunto de elementos que visam criar a condição ideal de discurso no sentido habermasiano.

Ora, da mesma forma que não existem dois relógios iguais, conseqüentemente não existirão observadores inerciais em posição de igualdade (embora sejamos teoricamente impelidos a aceitá-lo), também não vão existir duas sociedades ou dois grupos sociais com representações culturais iguais ou com elementos semióticos que sejam capazes de assegurar, com precisão terminológica, a existência de uma equivalência cultural, no entanto, a exemplo da Teoria da Relatividade, temos que aceitar o pressuposto da possibilidade de representação cultural e simbolicamente igualitária de todos os elementos envolvidos na prática do discurso.

Como ocorre na física, em que os dois relógios são sincronizados para definir um fator universal, baseado na relação entre os dois observadores inerciais (fator k), no Direito, é possível promover essa sincronização, por meio da prática 
discursiva. É o discurso jurídico que vai promover o instrumento relacional necessário para se formular o fator universal fundamental para a confecção de um conjunto de argumentos com força normativa e validade universal, sem, no entanto, prescindir de potencialidade crítica. Essa realização somente é possível do ponto de vista da teoria habermasiana, por conta de pressupostos que lançam mão de condições de igualdade e de liberdade discursivas.

Em complemento a essa vertente epistemológica emprestada pela Teoria da Relatividade, é possível, com base nos pressupostos de liberdade e igualdade, buscar auxílio na Teoria do Agir Comunicativo, que se justifica na filosofia da linguagem, para o estabelecimento de um parâmetro universal de discurso, a exemplo do fator $k$ da física relativa.

"A teoria do agira comunicativo, retirada dos estudos de filosofia da
linguagem, apresenta o propósito de buscar encontrar espécies de
competências universais, indo ao encontro das regras básicas de um
conhecimento pré-teórico. Para tanto, ela busca "isolar, identificar e
clarificar as condições requeridas para a comunicação humana" ,
possibilitando, assim, estabelecer uma compreensão da formação e
fundação de uma crítica emancipatória. Habermas demonstra que "a crítica
emancipatória não encontra em normas arbitrárias que nós escolhemos;
ela é fundada em estruturas de competências comunicativas
intersubjetivas". ${ }^{20}$ em

Essa intersubjetividade declarada encarece, ainda mais, o uso dessa teoria como arrimo para a formulação de uma metodologia discursiva que tenha por base os argumentos relativos aos Direitos Humanos, que possuam fatores que lhes confiram validade e universalidade sem roubar-Ihes o potencial crítico.

Será pela via discursiva que as matrizes culturais deverão se relacionar. A exemplo do fator $k$, o discurso, realizado sob as condições de igualdade e liberdade, como pressupostos pragmático-transcendentais, numa perspectiva da Ação ou da Razão Comunicativa, é que vai propiciar as condições ideais para que duas matrizes culturais diferentes se relacionem e fundamentem as bases normativas de um conjunto de direitos do homem.

O Professor Juliano Zaiden, ao tecer considerações sobre a imutabilidade das pressuposições pragmáticos transcendentais, ilustra a possibilidade de um conjunto de elementos discursivos ser instrumentalizado para a formação de uma

${ }^{20}$ BENVINDO, Juliano Zaiden. Racionalidade Jurídica e Validade normativa: da metafísica à reflexão democrática. Belo horizonte, MG: Argvmentum, p. 200-201. 
matriz normativa universal, haja vista que, para a teoria habermasiana, as bases normativas são lançadas e fundamentadas dentro da prática discursiva.

\begin{abstract}
"Concebidas pelo termo de princípio U - Havendo, em seu cerne, a renúncia em desenvolvê-las como fundamentação filosófica última - as pressuposições pragmático-transcendentais caracterizam-se como um princípio neutro (isento de carga moral-normativa) necessário de universalização da argumentação reflexiva que é implicitamente assumido por cada argumentador." 21
\end{abstract}

Dessa forma, a exemplo do que vimos anteriormente com o fator $k, 0$ termo de princípio "U" é, mutatis mutandi, o fator relacional universal que servirá de fundamento normativo para a constituição de proposições relativas aos Direitos Humanos, ou a qualquer outro conteúdo normativo que tenha por pretensão a universalidade, sem lançar mão de um potencial crítico. Nesse sentido ZAIDEN, afirma ainda, a capacidade reflexiva do conteúdo intersubjetivo que adquire valor e validade racional por meio do discurso, realizado sob os pressupostos pragmáticotranscendentais, viabilizadores do entendimento mútuo e do discurso racional.

"É, assim, "um específico princípio da indução aplicado ao domínio prático," que salienta a intersubjetividade como condição da validação. Como princípio transcendental fraco, ele apenas elucida a "irrefutabilidade fática de pressupostos de teor normativo", uma vez que o discurso concreto não prescinde dessas pressuposições.

Por decorrência, ele ultrapassa o âmbito de um consenso adquirido faticamente e derivado de uma tradição lingüisticamente mediada. Ele é, na verdade, uma premissa inevitável de toda comunicação, que também é passível de ser submetida a um teste continuado em que prevalecem as razões e os motivos e, não, o recurso à força - daí o seu cunho autoreflexivo." ${ }^{22}$

Note-se, que a exemplo do que acontecia com o fator $k$, o termo de princípio "U" é bidirecional e, ao contrário do que prevalecia no relativismo, não tende a enfraquecer o conteúdo essencial ínsito aos sujeitos participantes do discurso, pelo contrário, sua forma normativa nasce da composição discursiva, e como elemento relacional entre as duas "culturas", ele é o fundamento normativo que deve servir para validar o discurso tendente a compor uma base para a formulação de Direitos Humanos.

Entendemos que relativizar direitos significa a submissão de seus conteúdos proposicionais a um discurso realizado sob condições de igualdade de oportunidade de iniciativa e participação no diálogo (gleiche Chancen auf

\footnotetext{
${ }^{21}$ MILOVIC, Miroslav. Filosofia da Comunicação. Para uma Crítica da Modernidade op cit, p267 Racionalidade Jurídica e Validade Normativa op cit pág 211

22 Idem, ibidem.
} 
Dialoginitiation und -beteiligung), de igualdade de oportunidade de interpretação e de qualidade dos argumentos (gleiche Chancen der Deutungs- und Argumentationsqualität,) e de inexistência de falhas (ilusões) sobre as intenções desse discurso (keine Täuschung der Sprechintentionen).

Para dar suporte à nossas assertivas sobre a viabilidade da relativização de conteúdos relativos aos direitos do homem, lançamos mão de teorias que, embora fundamentem uma metodologia baseada em pressupostos fáticos diferenciados, são, epistemologicamente equivalentes. Guardadas as devidas proporções, o princípio "U", habermasiano, não é outra coisa senão o fator " $k$ ", da Teoria da Relatividade.

As semelhanças repousam no fato de ambos serem, metodologicamente, elementos pelos quais se pode e se deve refletir condições generalizantes e válidas para todos os envolvidos no processo de aferição. O fator $k$ é uma constante relacional universal e o princípio "U" guarda as proposições pragmático-universais, ambos fixam fatores de natureza diferente da dos sujeitos a que estão relacionados, e, na medida em que são estabelecidos, independem deles em seu conteúdo ontológico ou deontológico, por assim dizer.

\section{Uma visão sócio-antropológica do Direito}

A pretensão de cientificidade, independentemente do sentido epistemológico que se lhe pretenda, que permeia a necessidade de conhecimento no plano normativo, não pode prescindir do estudo dos fatos naturais e sociais que Ihe dão origem. Por isso, a ciência do Direito posiciona um conjunto de outros campos do conhecimento como instrumentos auxiliares no desvelamento do sentido normativo desses fatos. Esse primeiro contato do Direito com 0 fato social geralmente ocorre por meio de estudos afetos à sociologia, a quem incumbe 0 estudo e a sistematização dos fatos sociais, que se operacionalizam por meio de outros ramos do conhecimento como a física, medicina, psicologia etc.

Ocorre que, algumas vezes, apenas o estudo do fato social em si, é incapaz de explicar determinados fenômenos na ordem social normativa. Quando isso acontece, é necessário retroceder um pouco mais e focar o estudo na fonte primária emanadora do fato social, ou seja, no homem, ou melhor, no estudo dos grupos humanos. 
Tecidas essas considerações metodológicas sobre os fatores objetivos que poderiam dar ensejo a conjecturas a respeito de uma ordem universal de Direitos Humanos, é importante salientar que essa normatividade só é possível se os valores elencados pelos sujeitos ativos na prática discursiva não forem atingidos ou minorados, enquanto elementos informativos do discurso. Há que se formar o conteúdo normativo dos direitos em discussão sob os pressupostos de que falamos anteriormente.

A vertente sócio-antropológica fornece uma das diretrizes capazes de indicar a idoneidade ou impropriedade do conteúdo ou do grupo que vai participar da ordem normativa, sendo importante indício de sua validade normativa, por ser parte integrante de seu conteúdo.

Não fosse a diretriz teórica do trabalho e a sua limitada abrangência, dada sua natureza acadêmica e finalidade, seria impossível resistir ao desejo da realização de estudo de campo e observação do grupo escolhido como objeto de amostra, que é o povo de religião muçulmana. O parco material utilizado na pesquisa pode deixar escapar detalhes que, em muito, poderiam aperfeiçoar e corroborar com as afirmações aqui defendidas, o que, de maneira alguma, invalida a pretensão da pesquisa que é de lançar à discussão uma nova possibilidade e perspectiva de trabalho e uso dessa ferramenta jurídica poderosa que são os Direitos Humanos.

Gerrald Berreman ${ }^{23}$, que descreve alguns desafios metodológicos do trabalho de observação, teoriza os princípios fundamentais das relações entre o pesquisador e o seu objeto de estudo como de extremada eloqüência ao dissertar sobre a existência de uma relação entre o que chega para se estudar e o estudo que se realiza, às vezes, em conflitos, concordâncias e certo grau de imprevisibilidade. Aquele que estuda também é estudado e, de parte a parte, a relação envolve "controle e impressões".

As reflexões sobre esse teatro, os bastidores e a platéia - suscitadas por Erwing Goffman, inspiraram Berreman. No último caso, tem-se que informações inesperadas se revelaram quando formalmente não havia entrevista e, de certa forma,

23 BERREMAN, Gerald. Ethics versus Realism in Anthropology. In Ethics and the Profession of Anthropology. C. Fluehr-Lobban, ed. 1991. Philadelphia: University of Pennsylvania Press. Pp. 3871. 
revelavam-se os "bastidores". Infelizmente, acredita-se que esses "bastidores" não poderão figurar nesse trabalho, em função da própria limitação imposta, que vai além da deficiência temporal, atingindo o próprio objeto da pesquisa, que deve se limitar a uma apreciação monográfica do tema, ficando para um momento posterior maior aprofundamento nessas considerações.

A despeito de todas as limitações, sob as quais, apresentamos nossas desculpas, não seria possível desenvolver determinados argumentos, mesmo que em breves considerações, sem que considerássemos o importante papel que a antropologia desempenha nesse tipo de trabalho, seria impossível, dessa forma, adjungir o termo "relatividade" sem lançar mão de uma metodologia comparativa de bases antropológicas.

Clifford Geertz, afirma que a função do antropólogo não seria a da mera observação de outras culturas como complexos estruturais, mas procurar compreender os membros dessas culturas em seus pontos de vistas mais peculiares. Nesse sentido, Figueira aduz que:

"De fato, Geertz acredita que os fenómenos culturais podem "ser tratados como sistemas significativos, capazes de propor questões expositivas" e que "a antropologia sempre teve um sentido muito aguçado de que aquilo que se vê depende do lugar em que foi visto, e das outras coisas que foram vistas ao mesmo tempo". ${ }^{4}$ Ao tratar da "representação" e do "teatro" em Bali, Geertz , lembrando Weber, escreveu sobre o homem como estando "suspenso por teias de significação por ele próprio tecidas". Estas teias eram plurais - palavras, melodias, arquitetura, ritos - e nelas havia um "texto" a ser decifrado." ${ }^{24}$

Em nosso caso, o texto a ser decifrado diz respeito ao modo como os Direitos Humanos ganham significado e se operacionalizam a partir do conjunto de valores eleitos como prioritários. A ordem normativa necessita de ser preenchida com os elementos discursivos habilitados para servir de conteúdo normativo e de instrumento de controle das relações sociais.

Norbert Elias introduz conceitos como estranhamento, medo e fragmentação social, a partir do que desenvolve o significado do vocábulo de insider. Essa abordagem teórica é apropriada por Figueira como paradigma para o entendimento dos mecanismos relacionais de resistência e de estranhamento entre os diversos grupos sociais, pertencentes a comunidades distintas. Resistência e

\footnotetext{
${ }^{24}$ FIGUEIRA, Ricardo Rezende. Pisando Fora da Própria Sombra: A escravidão por dívida no Brasil. Rio de Janeiro: Civilização Brasileira, 2004. p. 58
} 
estranhamento são fatores que podem inviabilizar uma política de formação normativa.

Figueira também recorre a Dummont, utilizando-se de sua teoria analítica dos conceitos do individualismo e holismo, acentuada pelas reflexões sobre o indivíduo fora-do-mundo e dentro-do-mundo, e que permite uma melhor apreensão das nossas categorias mentais modernas. Com isso, contribuindo para uma melhor compreensão das relações entre o indivíduo e a sociedade em suas peculiaridades e semelhanças. Figueira recorre, sobremaneira, à concepção dummoniana do conceito de hierarquia, que pode servir de elemento informativo de como se podem concretizar as relações entre os diversos grupos sociais.

Por fim objetivo de citar alguns antropólogos e as suas teorias é, somente traçar um panorama dos diversos matizes teóricos sob os quais se poderiam tecer considerações, na seara da antropologia, com vistas a identificar os principais problemas que as culturas podem enfrentar em seus interiores e se esses óbices são passíveis de inviabilizar outros discursos com pretensões de validade universal, por negar a inclusão do outro no sistema normativo viabilizado pelo discurso.

\section{Da discussão sobre a proposição Direitos Humanos}

Depois de introduzir os elementos epistemológicos que podem fornecer a base científica para a formulação de uma nova metodologia para a aferição dos direitos do homem, seria, obviamente, necessário, tecer algumas considerações sobre como o discurso relacionado aos Direitos Humanos tem sido instrumentalizado e sobre quais pretensões tem ele se assentado.

Esse exercício é muito importante para a demonstração de que, o fracasso que as instituições tem experimentado no estabelecimento de uma ordem universal de Direitos Humanos dá-se ao fato de que esses direitos são declarados sem obedecer aos pressupostos que, antes, devem ser estabelecidos como elementos de controle da validade do discurso universal relativo a essa matéria e, depois operacionalizados sob condições que Ihes garantam a um conteúdo cuja validade não seja passível de questionamento pelos atores que compõe o teatro discursivo sob o qual a ordem normativa deve vigorar.

Quando tecemos anteriormente alguns contrapontos que identificaram a Teoria da Relatividade e a Teoria da Ação Comunicativa como técnicas para a 
aferência de um elementos relacional universal que, aferido a partir dos conteúdos dos sujeitos envolvidos, não lhes afetasse o comportamento, buscava-se fornecer uma via metodológica em que os Direitos Humanos pudessem ser forjados com as mesmas características fenomenológicas que apresentam hoje, mas com fundamentação essencialmente baseada na prática discursiva, sob o estrito controle de pressupostos pragmático-discursivos, e com aspectos de universalidade que não Ihes alienasse da possibilidade de crítica ao seu fundamento.

Desenvolvida a metodologia, resta saber se o conteúdo que povoa a matéria discursiva dos Direitos Humanos, da forma como vem sendo articulada, é capaz de fornecer o elemento material discursivo para a viabilização desse discurso. Nesse sentido, mostra-se relevante a consecução de uma análise histórica e antropológica, no sentido de descortinar a natureza dessa argumentação.

Já existem Declarações Universais de Direitos Humanos, nos moldes das mais variadas culturas e com os mais variados conteúdos. Depois de discutir e apresentar uma metodologia de validação do conteúdo proposicional, passaremos a uma análise perfunctória desse conteúdo, visando a aferir se há legitimidade de sua parte, tomados determinados pressupostos sobre a relatividade desses direitos.

Para tanto, a perspectiva histórica é importante no sentido de descortinar como vieram à lume esses conteúdos e sob quais pressupostos adquiriram eles a legitimidade e a pretensão de universalidade que reclamam para se fazerem valer em escala universal.

A proposição lingüística Direitos Humanos tal qual conhecemos hoje, e nos moldes em que figura nas diversas declarações universais, foi cunhada no início do século XVII, e pode-se dizer, o seu sentido é devido ao pensamento humanista e à idéia de direito natural desenvolvida pelo pensamento iluminista europeu. É portanto, a declaração de direitos que tem por base exclusivamente uma matriz ocidental de pensamento, e esconde um essencialismo que Ihe inviabiliza qualquer possibilidade de validade como escala universal de direitos do homem.

A modernidade ocidental consolidou o conhecimento do fenômeno social encerrado no termo Direitos Humanos como um conjunto de direitos subjetivos inerentes à própria condição humana. Direitos esses que possuem uma pretensão de validade universal. Nesse módulo, os Direitos Humanos tem sido o foco central do debate político e fundamento essencial para a instituição de um legitimado e legitimador Estado do Direito. 
Toda sociedade certamente terá uma proposição lingüística para denominar "humano" com maior ou menor abrangência, a exemplo do termo alemão Mensch. No entanto, o conjunto de obrigações e deveres que envolvem a proposição "Direitos Humanos", somente veio a constituir o sentido sob o qual se tem estruturado e legitimado a conduta estatal na sua vertente constitucional, depois dos adventos das Revoluções Burguesas do século XVIII e XIX. De lá pra cá, a doutrina jurídica tem acomodado e sistematizado esses direitos de uma forma típicaideal $^{25}$ em três categorias, uma jurídico-doutrinária, uma, como parte do direito internacional codificado e outra, como derivação natural de um desenvolvimento histórico.

É forçoso constatar que essas perspectivas sob as quais os direitos do homem, que aqui assumem características de direitos fundamentais, somente apresentam algum sentido se descortinados sob o cenário de um Estado capitalista em que seus estágios constituem reações dos diversos atores sociais, nos diversos estágios do capitalismo, a agressões, ou do Estado contra esses atores ou desses atores contra eles mesmos, sem esquecer que o teatro das trocas capitalistas é que vai dar a informação exata sobre os conteúdos que serão veiculados por esses direitos.

Na perspectiva jurídica, tratar-se-iam os direitos humanos de um direito pré- e supra-estatal, que deve ser declarado e reconhecido na Constituição de um Estado para conferir-Ihe e legitimar-Ihe a designação de Estado de Direito. Seriam os Direitos Humanos o núcleo fundamental de que não pode prescindir qualquer estatuto que tenha por pretensão a declaração e limites do Estado frente às garantias dos indivíduos e de seus cidadãos, como forma de indicação do sentido na busca do desenvolvimento humano na busca do bem comum e da justiça social.

Pela perspectiva internacional, os Direitos Humanos permeariam um conteúdo que faz parte da Declaração Universal dos Direitos Humanos, bem como

\footnotetext{
25 Idealtypisch lassen sich drei Kategorien von Menschenrechtsdefinitionen unterscheiden. Aus juristischer Perspektive handelt es sich um vor- und überstaatliche Rechte, die der Staat nicht nach Maßgabe seiner Verfassung verleiht, sondern die vorkonstitutionell gelten und allenfalls deklaratorisch anerkannt werden können95. Mit ihrer Kodifizierung in der Allgemeinen Erklärung und in zahlreichen internationalen Konventionen wurden die Menschenrechte zum Bestandteil des Völkerrechts. Historisch lassen sich die Menschenrechte einteilen in drei Dimensionen: die als "liberale Abwehrrechte" (Riedel 1989:53) oder als "politische Schutz- und Teilhaberrechte" (Heinz 1987:323) bezeichneten Menschenrechte der ersten Generation, die wirtschaftlichen, sozialen und kulturellen Menschenrechte der zweiten Generation und die der dritten Generation, die sich in den Forderungen auf das Recht auf Entwicklung, Frieden, Selbstbestimmung und Partizipation artikulieren. ARNDT Christina.Menschenrechte - partikularistische Ansätze zur Begründung ihrer Universalität- Dissertation zur Erlangung des Grades der Doktorin der Philosophie im Fachbereich Philosophie und Sozialwissenschaften der Universität Hamburg, Hamburg, Hamburg 2000. p-23.
} 
de um conjunto de outras declarações e convenções sobre a matéria como parte do direito internacional.

Já do ponto de vista histórico, os Direitos Humanos poderiam ser concebidos sob uma perspectiva tridimensional, que vai desde os direitos de defesa do liberalismo (liberale abwehrecht) ${ }^{26}$, tidos como de primeira geração, passando pelos direitos sociais e culturais, de segunda geração, chegando aos direitos de terceira geração como direitos ao desenvolvimento, à paz, à autodeterminação.

Sem muito esforço, é possível observar que o conjunto dos elementos que compõem os esforços argumentativos fundamentais na justificação do discurso que envolve os Direitos Humanos não contemplaram outras experiências culturais, que não a cultura ocidental européia. Essa fissura no conteúdo discursivo dos Direitos Humanos faz com que esse sistema sucumba à criação de fortíssimos argumentos contrários à instituição de uma ordem universal de direitos que conglobe toda a toda a humanidade.

No próximo tópico, há um sucinto aprofundamento nessa assertiva, que utilizaremos como ponto de partida para sustentar o argumento da necessidade de relativização dos Direitos Fundamentais.

\subsection{Desenvolvimento histórico do argumento humanitário na sociedade ocidental}

É possível afirmar, sem preocupação, até mesmo em função da abrangência da afirmação, que os Direitos Humanos, na sociedade ocidental, com a forma e a função que possuem hoje, são objeto de um longo e constante diálogo entre segmentos sociais, grupos científicos, políticos e religiosos que culminaram por formular um cenário propício ao desenvolvimento dos valores sob os quais se estruturarão os argumentos que conferem validade normativa para as relações sociais. No entanto, estão esses direitos longe de representarem a única via para a realização desse conteúdo normativo.

Somente identificando o fenômeno dos direitos e garantias afetos aos Direitos Humanos como um fenômeno histórico, resultado de um debate entre diversos

\footnotetext{
${ }^{26}$ RIEDEL, Eibe. Die Menschenrechte der dritten Generation als Strategie zur Verwirklichung der politischen und sozialen Menschenrechte. In: Esquivel, A. Perez (Hrsg.): Das Recht auf Entwicklung als Menschenrecht. Von der Nord-SüdKonfrontation zur Weltsozialpolitik. Zürich, S. 49-69.
} 
atores no bojo de uma determinada sociedade, é que é possível aventar a possibilidade de relativização desses direitos em relação ao grupo social que dele se instrumentaliza.

Teorizar essa "instrumentalização" dentro das perspectivas almejadas por esse trabalho, só é possível se lançarmos mão, ainda que perfunctoriamente, do conceito de razão comunicativa habermasiana, ${ }^{27}$ no sentido de uma interação lingüística compartilhada, ${ }^{28}$ que se obtém por meio de um contexto de interação e inserção de um uso lingüístico orientado para a comunicação.

A fim de entender os principais argumentos que fizeram parte, na história da sociedade ocidental européia, da composição dos conceitos e valores que povoam a visão social e jurídica dos Direitos Humanos, é importante que se faça uma pequena imersão na língua dos acontecimentos que, na sociedade ocidental, culminaram com as declarações universais dos direitos do homem.

Esse é um exercício de extrema importância, visto que a visão histórica, tal qual é veiculada no meio acadêmico, sucumbiu à tendência de aceitar o argumento da existência de um desenvolvimento histórico, sem interrupção, entre o pensamento helenístico e a sua apropriação posterior pela cultura românica, na via do humanismo e neoclassicismo, ${ }^{29}$ e as declarações universais dos direitos do homem, no bojo das Revoluções Americana e Francesa.

No mundo ocidental costumam-se identificar como momento crucial de emergência das discussões que levaram à decisão política de proteção desses

\footnotetext{
27 A Teoria do agir comunicativo, retirado dos estudos de filosofia da linguagem, apresenta o propósito de buscar encontrar espécies de competências universais, indo ao encontro das regras básicas de um conhecimento pré-teorético. Para tanto, ela busca "isolar, identificar e clarificar as condições requeridas para a comunicação humana", possibilitando, assim, estabelecer uma compreensão da formação e fundação de uma crítica emancipatória. A primeira importante conclusão que se pode retirar do pensamento habermasiano é a afirmação da intersubjetividade. De fato, Habermas é categórico ao estabelecer a intersubjetivade a partir de uma compreensão social manifestada na comunicação. É essa relação "sujeito/co-sujeito" que dá as bases para uma nova compreensão do mundo. Ao enfatizar essa nova relação, o próprio conceito de mundo é alterado. Há sem pré por trás desse contato com a realidade um pressuposto pragmático: " para que possam se relacionar com algo, seja na comunicação sobre fatos ou nas relações práticas com pessoas e objetos, devem - cada um por si, mas em concordância com todos os outros - partir de um pressuposto pragmático. A linguagem assume, então, um papel central para a consciência e a relação do sujeito com o mundo. Nessa premissa argumentativa, constrói-se a possibilidade de uma racionalidade comunicativa. BENVINDO, Juliano Zaiden.ibidem;

28 Die sprachlich vermittelte Interaktion, die durch die funktionale Einbettung des verständigungsorientierten Sprachgebrauchs in einen Handlungskontext kommt, nene ich >>kommunikatives Handeln<< (s.10). HABERMAS, Jürgen, Erläuterung zum Begriff des kommunikativen Handels in Philosophische Texte Band 2. Sudienausgabe Suhrkamp. Suhrkamp. Frankfurt am Main. 2000. pág 152.

O Humanismo e o Classicismo compõem o argumento ideológico que dá suporte ao conjunto de mudanças operadas na cultura e na sociedade européia e americana, nos séculos XV e XVI. Surgido em contraste com o pensamento e período Gótico, compõe a fase de transição da Idade Média para a Idade Moderna, da cultura de matriz teocrática medieval para uma ordem intelectual secular. O pensamento escolático, em voga na Idade Média, deu lugar ao interesse pelos textos da antiguidade clássica (em Latim e Grego).
} 
direitos, o iluminismo, como corrente filosófica, e a Revolução Francesa e Americana, como pontos de mudanças estruturais.

Nesse esteio, é possível delinear o conteúdo e o momento em que se ofereceu uma mudança paradigmática no discurso justificador do poder constituído. É nesse teatro de efervescência cultural que vão ter lugar os argumentos que darão lume às declarações universais dos direitos do homem, que, mais tarde, assumirão a pretensão de universalidade, avocando para si e, de per se, as pretensões de essencialidade e de legitimidade no reconhecimento do rol de direitos que compõem o conjunto das garantias do homem frente ao Estado.

Como portador legítimo do uso da violência, o Estado se deve mostrar consentâneo com as descrições e formatos desses direitos que são a legitimação, como marco civilizatório, do Estado de Direito. O problema é que o Direito fundado em uma matriz cultural ocidental não deixa qualquer outra possibilidade de reflexão sobre os seus pressupostos e requisitos para outras matrizes culturais, que não aquela em torno da qual for anteriormente formulado.

Sob essa perspectiva, os Direitos Humanos seriam forjados essencialmente ao arrimo da matriz da cultura ocidental e não comportariam qualquer outro tipo de complementação ou suplementação, carecendo de potencialidades reflexivas que, como veremos mais adiante, provocaram e provocam um conjunto de reações, por parte de outros ramos culturais de origem não-ocidental, no sentido de contra-argumentar as vantagens e desnudar os principais problemas que surgem ao não se considerar os componentes não ocidentais na escala de valores que devem ser ponderados para a tessitura de um conjunto Universal de direitos do homem. Esse problema já foi levantado anteriormente quando nos referimos à originalidade dos direitos humanos quanto à sua origem na cultura ocidental européia.

Ao contrário da crença na existência de regras de direito e de eqüidade, que sempre existiram como conteúdo justificador das relações entre os grupos sociais, não se pode, propriamente, afirmar que tenha existido um conceito ou idéia que se assemelhe ao que conhecemos hoje, sobre a determinação dos direitos ou garantias individuais.

Como afirmamos alhures, as menções feitas a um direito do homem (jus hominum), na cultura grega ou latina, não bastam para se inferir sobre a existência de uma consciência explícita de direitos inerentes ao ser humano, haja vista a 
própria constituição daquelas sociedades, em que o patriarca era o único a deter os direitos de se manifestar como cidadão, estando todo o seu clã sob a sua justiça privada e domínio patrimonial. Essa constituição societária não favorece, por sua própria natureza, a possibilidade de se discutir a existência de uma esfera de individualidade que deva ser respeitada pelos demais componentes do grupo, a contar pela existência de relações sociais, como a escravidão, que não comportam quaisquer justificativas dentro de um sistema que se baseie no reconhecimento de direitos inerentes à pessoa humana.

Embora possamos identificar, já no bojo dessas culturas, determinados termos lingüísticos como afetos ao grupo semântico que constituiriam o conceito integralizante do círculo semântico afeto ao termo Direitos Humanos, tais como liberdade, garantias fundamentais, etc., não existe menção expressa a esses termos na acepção tal qual como pretendemos, que sejam operacionalizados dentro do cenário que envolve os direitos fundamentais.

Os gregos, como se pode depreender das obras de Aristóteles, faziam, constantemente, menção a direitos, to dikaion, como elemento justificador da relação dos cidadãos com a propriedade e a participação política. No entanto, sabese que esse conceito e a relação a que faz menção, dizem respeito somente a um diminuto grupo de patriarcas, e que grande parte dos demais membros do grupo estavam alijados da propriedade e da convivência e participação políticas, reservadas, por costume e tradição, a uma parcela diminuta dos de seus componentes. O próprio filosófo em sua obra A Política (livro I, Cap. 5, 1254b) , defende o argumento de que muitos homens eram escravos devido à sua própria natureza. 


\subsection{Os Direitos Humanos são criação do mundo ocidental?}

Verifica-se que todas as perspectivas do objeto de estudo nesse trabalho, são apresentadas e refletidas no "modus vivendi" e na cultura ocidental. As definições que ora se levantaram, no tópico anterior, tomaram por fundamento:

a) O desenvolvimento histórico e econômico das sociedades européias e americanas, que criaram uma ideologia liberal de atuação dos mercados, forçando uma atitude abstencionista por parte do Estado, que fora levado a deixar atuar (laissez faire, laissez passer), a "mão invisível do mercado", que deu lume aos chamados direitos negativos.

b) As tratativas jurídicas, ou juridicizantes, encabeçadas por órgão criados por países de cultura ocidental, que dão corpo a um direito positivo internacional;

c) O direito proclamado internacionalmente, que tem como origem as declarações universais e outros tratados ou convenções internacionais, emanado por entidades que avocam a si a legitimidade discursiva em favor de todo o planeta, mas que não possuem representatividade qualitativa e quantitativa expressiva para sustentar um poder regulador de alcance universal, e assim instituir direitos positivos cogentes com validade internacional.

d) Outros argumentos levantados em agenda de grupos internacionais como prioridade, a exemplo de alguns direitos sociais e de meio ambiente equilibrado.

A pretensão de universalidade encontra-se estampada prima face na própria denominação dos institutos, v.g Declaração Universal dos Direitos do Homem. Essa universalização, no entanto, não passa inconteste por outros grupos culturais, não tão identificados como o pensamento ocidental europeu.

O objetivo dessas breves considerações é, dentro das limitações que a natureza acadêmica desse trabalho impõem, traçar o panorama sobre a deriva etimológica e semiótica que teria conduzido o sintagma nominal "Direitos Humanos", ao encontro do significado que aponta para um conjunto de valores com pretensão valorativa universal, melhor dizendo, em que momento a proposição lingüística "Direitos Humanos" passou a ter o significado político-sociológico que possui hoje, e que se espraia por todas as áreas das relações humanas, com reflexos, inclusive, integrativos, nos sistemas de resolução de conflito . 
É absolutamente imperativo, que qualquer apreciação sobre o tema, por deter em seu cerne a mínima intenção de tocar, dentro das limitações acadêmicas impostas, a matéria dos Direitos Humanos, sob o prisma da relatividade, aprecie a forma como se deu o debate em torno dos conteúdos sob os quais se viabilizou a formação do conceito moderno de Direitos Humanos e, tangencialmente, o próprio sentido e conotação do termo justiça.

No caso, é muito importante saber, como a intelligentsia, ao tratar do tema, justifica a sua criação conceitual, nos moldes em que conhecemos hoje. Sem lançar mão desse exercício mental, é praticamente impossível espelhar outras possibilidades de entendimento da semântica do termo Direitos Humanos. Esse exercício mental objetiva fornecer argumentos e entender o por que de não ter sido possível a formatação de um fator universal, nos moldes expostos acima, para que se viabilizasse um conteúdo universal de Direitos Humanos, cuja validade não fosse questionada, por estar assentada no fundamento racional de uma matriz discursiva baseada no consenso.

O que será aqui exposto em forma de instigação, vez que espera-se que encontre ressonância em futuros trabalhos, é de grande importância para a pacificação social, tanto em nível nacional, quanto internacional, haja vista o seu sucesso como mecanismo empregado no controle da atuação do Estado e na justificação das suas políticas e atos.

Nos próximos tópicos, buscar-se-á introduzir a discussão sobre a perspectiva essencialista dos Direitos Humanos, ao mesmo passo em que serão apresentadas outras vias interpretativas desses direitos, que não povoam o seu conteúdo por sua relativa falta de coincidência entre os argumentos justificadores das garantias inerentes a esses direitos.

Embora tenhamos, acima, firmado o conteúdo dos Direitos Humanos, como ora se apresenta no cenário político internacional, dentro de uma matriz cultural que gira em torno do humanismo e do iluminismo, é importante descortinar a existência de linhas de abordagem desses direitos, que os remetem para origens um pouco mais distantes, na linha do tempo. Fa-lo-emos sem, no entanto, desmerecer o que, até agora, se afirmou sobre a pretensão, essencialmente, ocidental desses direitos, haja vista que todos os esforços envidados em conferir uma origem ao pensamento que inaugura as garantias do ser humano frente à entidade estatal, no mundo ocidental, tenham, de alguma maneira, atribuído, na cultura ocidental 
européia, às Revoluções Americana e Francesa, sem no entanto afastarmos o substrato cultural formado pela cultura greco-latina, em especial pela moral cristã, o ponto de partida para a formatação desses valores morais e, conseqüentemente, sua incorporação ao direito positivo constitucional nas sociedades de estrutura política de vertente ocidental.

Conquanto esse seja o pensamento dominante nos livros didáticos, conferindo à origem dos direitos fundamentais um cerne eminentemente iluminista e humanista, existem pensadores que defendem a derivação desses direitos de outras correntes de pensamento. O que há em comum com todos eles é que todos procuram descortinar a origem, o epicentro, do qual tenham emanado as idéias fundamentais que formaram e conformaram os Direitos Humanos enquanto pensamento filosófico, e matriz político-estatal de fundamento constitucional, a partir de correntes de pensamento originárias da cultura ocidental, sem considerar que possam existir traços desses direitos em outros sistemas jurídicos.

A cultura greco-romana já fazia menção ao termo "direitos do homem" como se pode observar nas obras de Cícero e Sêneca, que já aludiam a um ius hominum com um sentido de "ius humanum", o que também é encontrado nos escritos de São Thomas de Aquino ${ }^{30}$, no entanto, pouco se sabe sobre o campo de abrangência desses termos, no que diz respeito ao Direito. Se eles apenas faziam menção a um direito criado pelo homem, em contraposição ao direito natural, e, portanto, não faziam referência a um direito "para o homem" e sim "pelo homem" ou se, de fato, abrangeriam uma esfera de direitos imanentes ao homem, em suas qualidades essenciais, até o limite em que se pode interpretar o circulo semântico do termo humano para a época.

O filósofo alemão Georg $\mathrm{Picht}^{31}$, à guisa de exemplo, afirma que a derivação da idéia de Direitos Humanos teria origem no antigo estoicismo, que teria assentado as bases metafísicas para a confecção de conceitos como dignidade da pessoa humana e Direitos Humanos. Como resultado dessas constatações, esse

\footnotetext{
30 Bei Cicero und Seneca ist bereits von einem "ius hom inum " bzw. "ius humanum " die Rede und auch Thomas von Aquin benutzt diesen Terminus.Es ist jedoch um stritten, ob sie dam it lediglich eine Unterscheidung zw ischen den Gesetzen treffen wollten, die vom Menschen geschaffen wurden und denen, die natur- bzw. gottgeben sind. In den allgemeinen Sprachgebrauch findet die Bezeichnung erst Ende des 18. Jahrhunderts Eingang (Schmale 1993:20). In : Christina ARNDT, ibidem 31 BIELEFELDT, Heiner. "Western" versus "Islamic" Human Rights Conceptions?: A Critique of Cultural Essentialism in the
Discussion on Human Rights Political Theory, Vol. 28, No. 1. (Feb., 2000), pp. 90-121.
} 
pensador chega a afastar, por completa incompatibilidade essencial, a possibilidade de uma ordem global normativa de Direitos Humanos.

O advogado e historiador alemão, Wolfgang Finkentscher, ${ }^{32}$ identifica e localiza os fundamentos históricos concernentes aos Direitos Humanos na sociedade holandesa do século XVI, que teria, por meio da revolução protestante contra a ocupação da igreja católica, lançado mão de argumentos que embasam, hoje, a teoria fundamental de proteção aos Direitos Humanos. O historiador afirma que, a despeito dos intentos "seculares" que estariam por trás das discussões protestantes por direitos e liberdades, existia um dissenso no que diz respeito ao discurso praticado com relação aos dominados, o que, a nosso ver, já seria, de plano uma espécie de relativização, do pensamento libertário com reflexos antitéticos.

Tecidas essas considerações, questiona-se se os fundamentos filosóficos, sociológicos e jurídicos para instituição de um conjunto de prerrogativas protetoras de Direitos Humanos seriam, exclusivamente, de matriz ocidental, ou se poderiam existir traços comuns em outras culturas, de matriz não-ocidental, que pudessem indicar deriva ou desenvolvimento em direção à consolidação desses direitos, em um sistema jurídico ou moral.

Mastronardi ${ }^{33}$ aponta a existência de uma relação muito íntima entre a cultura e o sistema jurídico de uma determinada sociedade, atacando veementemente a pretensão de universalidade do pensamento jurídico. O professor indica a existência de um grupo ou de um círculo de direito europeu, que conviveria ao lado de culturas jurídicas de vertente asiática, como a japonesa, a chinesa e a indu.

Ao contrário do que se pode fazer inferir do conteúdo expresso no texto das declarações e tratados que tratam de Direitos Humanos, outras sociedades têm enxergado uma pretensão de poder subjacente à essa universalidade que se projeta em uma imposição do modo de vida e dos valores de um grupo social,

\footnotetext{
32 Idem, ibidem.

33 O círculo occidental de pensamento jurídico, a despeito de algumas de suas diferenças é tomada como um conjunto homogêneo, mencionda a sua origem germano-românicas, o círculo japonês, em que as normas para a composição dos conflitos são informados por meio das normas de conduta social, sendo o direito ocidental, introduzido pela ocupação americanda durante a segunda guerra mundial, apenas uma fonte subsidiária quando essa forma de resolução do conflito vier a falhar (trad livre).MASTRONARDI, Philippe, Recht und Kultur: Kulturelle Bendigtheit und Universaler Anspruch des juristischen Denkens. Disponível em http://www.Zaoerv.de. 2001, Max-Planck-Institut für ausländisches öffentliches Recht und Völkerrecht.
} 
economicamente poderoso e politicamente hegemônico, em detrimento de outros grupos sociais.

Algumas tentativas de lhe contrapor argumentos culminam por produzir discursos com a mesma pretensão de validade universal, que tornam incompatível a convivência simultânea entre os argumentos formulados por esse grupo, o que inviabiliza, sobremaneira, a possibilidade do estabelecimento de um conjunto de direitos que possuam validade para esses grupos sociais, mutuamente.

Essa contrariedade é visível na assertiva de algumas pensadores de matriz muçulmana, que ao discorrer sobre Direitos Humanos avocam a sua ancestralidade e originalidade nas sagradas escrituras da religião Islã. ${ }^{34}$ Segundo essa corrente dissidente, as origens dos direitos do homem estariam em suas sagradas escrituras e as declarações de Direitos Humanos contido nas Declarações Universais apresentariam imperfeições. Esse discurso não é outro senão o mesmo discurso da intolerância ocidental visto por uma matriz discursiva oriental islãmica, embora o texto que traga essa afirmação, traga-a sob o título de preconceitos atuais sobre os direitos humanos no Islã, são discursos excludentes e, portanto, inaptos a compor uma mesa discursiva de onde pudessem ser viabilizados um conjunto de direitos de base e pretensões universalistas.

Não é difícil encontrar manifestações políticas e culturais que tem por escopo contraditar a tendência a visualizar a origem e os fundamentos dos Direitos Humanos como um fenômeno gerado e gestado no pensamento ocidental. A maioria das pesquisas realizadas nesse trabalho, revelaram que os direitos do homem teriam a sua origem na deriva histórica que vai da Revolução Inglesa, a partir da Carta de 1215, até as Revoluções burguesas do Séc XIX. Esse, portanto, é o argumento prevalecente.

O mundo acadêmico insiste em perpetrar essa espécie de ideologia, que é frequentemente encontrada nos livros jurídicos. Essa insistência em conferir a esses direitos uma origem nas Revoluções Burguesas dos séculos XVII e XIX, ou quando muito, a busca acanhada por traços e similaridades entre fragmentos de conteúdos das declarações de Direitos Humanos e elementos da cultura greco-latina, fatos e pensamentos do cristianismo, e outros elementos sociais ligados à cultura ocidental,

\footnotetext{
${ }^{34}$ Circa quattordici secolli fa I'Islam stabili molti di questi diritti all'interno dell' iluminato sistema della Shariah (legge e giurispredenza islâmica). Faz cerca de quatorze séculos que o Islã estabeleceu muitos desses direitos no interior do iluminado sistema do Shari'ah. (trad. Livre) AL-SHEHA, Abdur-Rakhman ibn Abdul Karim, Pregiudizi correnti sui diritti dell'uomo nell'Islam. subhanaka-allahumma. 2001.
} 
acabou por incitar uma guerra silenciosa e um antagonismo feroz às idéias que são permeadas pelos conceitos que envolvem os Direitos Humanos.

Essa atitude imbuiu a crença de que esses direitos seriam um criação exclusiva do ocidente, o que dirigiu as discussões em torno dos Direitos Humanos a um essencialismo monolítico, que não ficou imune a críticas e muito menos deixou de encontrar a sua antípoda em outras culturas.

A Declaração de Direitos Humanos no Islã do Cairo (Cairo Declaration on Human Rights in Islam - CDHRI) é um exemplo dessa contraposição, criada pelos países membros da Organização da Conferência Islâmica, em 1990, declara que a fonte primordial para a consideração dos Direitos Humanos na cultura islâmica é o shari'ah , a lei sagrada do Islã, que muitos acreditam que seja derivada de outras duas fontes primárias da lei Islâmica: as revelações divinas inscritas do Corão e os exemplos deixados pelo Profeta Maomé no Sunnah. O discurso que envolve os direitos do homem no mundo muçulmano ataca vorazmente o conteúdo das Declarações Universais, por ser incompatível com o conceito de dignidade formulado no bojo daquelas sociedades ${ }^{35}$

Vê-se, que no cenário internacional os argumentos sobre os direitos do homem, ao contrário de apresentarem potencialidades integrativas, estão assentados em argumentos disjuntivos, que se voltam à exclusão um do outro. $\mathrm{O}$ discurso exclusivo é bilateral.

Ao contrário do que se é levado a pensar, o discurso disjuntivo, segregador e exclusivo, também encontra representação no ocidente. Apenas para apresentar o fenômeno de como esses argumentos se articulam em contraposição, pode-se demonstrar que as considerações tecidas no bojo das próprias Nações Unidas, que avaliaram a Declaração Universal do Cairo, estão povoadas de argumentos negativos e não-inclusivos. $O$ item 10 do documento ${ }^{36}$ critica a $^{2}$

\footnotetext{
35 I principi elencati dalle moderne organizzazioni internazionali sono caratterizzati da mancanze concettuali, da errori nella formulazione e da ingiustizie nell'applicazione. Sono subordinati a programi politici, a pressione economiche Ed a preconcetti culturali e si portanto dietro i residui dell' colonialismo e dell' imperialismo. Tali diriti, spesso, sono proclamati e stabiliti non per l'interesse di tutti gli esseri umani, ma piuttosto a vantaggio di determinati governi, organizzazioni e potenti gruppi com particolari interessi.Ciò diventa più evidente quando, come possiamo osservare ovunqu, molti dei nostri Fratelli soffrono Le peggiori delle altrocità e ciononostante non vi è nessuna organizzazione che difenda veramente i poveri ed $\mathrm{i}$ deboli. Idem, ibidem;

${ }^{36}$ NAÇÕES UNIDAS. 2008 Human Rights Council. Promotion and Protection of all Human Rights, civil, Political, Economic, Social and Cultural Rights, Including The Right to development. Joint written statement submitted by the Internacional Humanist and Ethical Unio (IHEU), a non-governmental organization in special consultative status, the Association for World Education (AWE) and the Association of World Citizens (AWC), non-governmental organizations on the Roster. U.N. Doc. A/HRC/7/NGO/96 4 MARCH 2008. Disponível em: < http://www.iheu.org/node/2949>. Último acesso em: 03 jan.. 2010.
} 
Declaração do Cairo e assume que existe uma limitação dos direitos por parte do shari'ah, islâmico e que, essa limitação, ao contrário de complementá-la (à Declaração Universal dos Direitos Humanos da ONU), prejudica muitos dos direitos a que ela supostamente garantiria.

Quando nos referimos a uma antípoda do essencialismo cultural ocidental em matéria de Direitos Humanos, estamos a fazer menção ao arcabouço argumentativo que o mundo muçulmano vem esboçando, no sentido de contra argumentar a origem desses direitos, avocando a própria religião muçulmana como epicentro e fundamento, ${ }^{37}$ e portanto, não menos essencial e não menos acrítico que a verdade filosófica e política das revoluções burguesas no ocidente.

A contradita ao essencialismo ocidental na percepção dos Direitos Humanos é capitaneada por um grupo de pensadores de matriz cultural nãoocidental, no entanto, para não nos afastarmos do objeto de apreciação desse trabalho, focaremos na vertente muçulmana dos Direitos Humanos, que apresenta e é representada, como observamos acima, por um grupo de pensadores voltados à explicar origem dos Direitos Humanos dentro do próprio fenômeno do islamismo. Portanto, para esses pensadores, a própria religião islâmica já traz em seu conteúdo essencial as declarações do conjunto de direitos necessários para uma existência humana digna, ${ }^{38}$ e opera esses direitos a partir da idéia de um sistema de respeito ao ser humano que tem por base sua natureza e condição de criatura no mundo criado.

Essa atitude, afasta por si só a possibilidade de um consenso sobre a matéria, e portanto, limita o ambiente em que o discurso sobre os Direitos Humanos entre essas duas culturas pode ocorrer, a um espaço muito restrito em que não se podem garantir condições de igualdade e de liberdade discursivas para ambos. A essencialidade da origem dos Direitos Humanos, avocados nas duas culturas conflitantes, afasta a possibilidade de argumentação crítica.

\footnotetext{
${ }^{37}$ Alcuni nazioni Ed arganizzazioni internacionali, come Le Nazioni Unite, fanno insistentemente appello ai príncipe che mirano a garantire i diritti umani. Circa uattordici secoli fa I'Islam stabili molti di questi diritti all'interno dell'iluminato sistema della Shari' ah (legge e giusrisprudenza islâmica). Idem, ibidem.

38 “il nostro totalle credo nella verità e nella giustizia dei diritti e dei principi islamici è dovuta al fato che è Allah, il Misericordioso e l'único Creatore dell'uomo, a rivelarli (i diritti umani). Egli as perfetamente cio che è bene per la Sua creazione in ogni momento, ciò que giova o nuoce l'uomo, cio che lo rende felice o triste, ciò che lo porterà al sucesso o alla sventura. Egli ha creato, dalla sua conoscenza e generosità, lê leggi migliori per l'individuo che soddisfano i bisongni essenziali di tutte le Sue creature sulla terra e permettono um vita prospera, sicuyra ed felice. Idem, ibidem.
} 


\subsection{Principais problemas de uma perspectiva essencialista dos Direitos Humanos}

O sentido e a natureza da ciência jurídica permitem, sem equívocos, uma prospecção que tenha por base esse caráter hermenêutico que seja, minimamente, dúplice: uma de matriz histórica e antropológica, como método relativo às ciências do espírito (geistwissenschaft) e outra de natureza epistemológica de viés neopositivista, como método afeto às ciências da natureza.

Essa metodologia há de emprestar-nos a linguagem adequada para operar a fuga do princípio fundante e fundador sobre o qual se impõe o primeiro e mais importante limite a ser vencido nesse trabalho, qual seja, a percepção dos Direitos Humanos como sendo de origem exclusivamente ocidental com base principiológica e poder ilocucionário essencialista a justificar-se como a única possibilidade e força autenticadora para a formação de Estados de matriz democrática de Direito.

A escolha metodológica não foi aleatória e buscou inspiração e base nos fundamentos que compuseram as primeiras críticas à natureza essencialista dos Direitos Humanos, ${ }^{39}$ partindo da escola do relativismo cultural ${ }^{40}$ que, a despeito de todos as ataques sofridos ao longo dos últimos anos, foi a primeira corrente de pensamento das ciências sociais a fazer frente ao etnocentrismo ocidental, que tomava conta do meio científico já nas primeiras décadas do século $\mathrm{XX}$.

A referida escola, rompendo com a idéia de uma matriz social, cultural e, em nosso caso, jurídica de base exclusivamente ocidental, apontou para a possibilidade de formação de conteúdos aptos a compor um discurso voltado à justificação da existência de direitos inerentes à pessoa humana, dentro das particularidades sobressalentes de cada grupo social, cultural ou religioso, passo de extrema importância para afastar o uso do discurso jurídico das pretensões valorativas qualificativas, que a política internacional tem-Ihe conferido, fazendo-o

\footnotetext{
39 (...)Pollis and Schwab , two representatives of cultural relativism and most outspoken critics of universal human rights. Pollis and Schwab argue that since human rights originated historically Western Europe and North America, they are essentially connected - and indeed confined- to the cultural and philosofical concepts of the Occidental Tradition. ( BIELEFELD, Heiner, Wester versus Islamic Human Rights Conceptions? A Critique of Cultural Essentialism in the Discussion on Human Rights in Political Theory, Vol 28, No 1 (Feb., 2000), pp. 90-12).

40 Segundo essa escola de pensamento, as crenças e ações de um indivíduo podem ser entendidas por outros indivíduos não pertencentes ao mesmo grupo tendo-se por base a sua cultura. Essa teoria tem fundo antropológico e carrega um conteúdo axiomático determinista.
} 
desempenhar um papel colonizador e civilizatório agressivo para com os povos de matriz cultural não-ocidental.

Essa vertente teórica fundou os primeiros argumentos que disponibilizaram uma outra via à perspectiva universal dos Direitos Humanos e descortinaram o argumento da inquestionabilidade de sua origem nas Revoluções Burguesa Européia e Americana, permitindo argumentar, contrariamente, aos discursos que postulavam a apropriação do modo de pensar ocidental e à renúncia a qualquer manifestação cultural que, fenomenologicamente, apresentasse-lhe contrária, como pressuposto essencial para o reconhecimento de um esforço político rumo a um desenvolvimento.

Foi, portanto, com base no relativismo cultural, de matriz sócioantropológica, que surgiu a inspiração e o substrato para a tessitura dessas considerações, sem contar com sua importância pretérita para a abertura das possibilidades analíticas que ensejaram, nas décadas anteriores tomar arrimo a uma perspectiva de aproximação do fenômeno Direitos Humanos, com base em estudos fundados na Antropologia Cultural.

Aliando-se aos argumentos que se possibilitaram aventar, a partir de uma perspectiva multiculturalista, a abordagem histórico-descritiva de sistemas morais e de suas representações no pensamento jurídico, ainda que breve, possibilita-se o reconhecimento de fatores que influíram na formação e inclusão do discurso dos Direitos Humanos nesses sistemas, bem como a identificação da forma como se operam sobre os substratos morais nessas sociedades. O argumento muitas vezes pode fugir um pouco do juridiquês e tangenciar o substrato antropológico, que, algumas vezes, pode ser imperceptível à imposição de uma matriz jurídica de base positivista, cuja natureza é, confortavelmente, dada à ignorância despreocupada das idiossincrasias culturais.

A lente sócio-antropológica, trazida e esse estudo, tem o condão de propiciar, a visão relativa necessária, escapando das críticas tecidas ao multiculturalismo, ${ }^{41}$ que, - à guisa de tentar resolver os problemas surgidos com 0

\footnotetext{
41 The city of Bradford provides a very good example of how the institutionalisation of multiculturalism undermined political struggles, entrenched divisions and strengthened conservative elements within every community. In April 1976, 24 people were arrested in pitched battles in the Manningham area of Bradford, as Asian youth confronted a National Front march and fought police protecting it. It was seen as the blooding of a new movement. The following year, the Asian Youth Movement was born. The next few years brought further conflict between black youth and the police, culminating in the trial of the Bradford 12 in 1981. Twelve young Asians faced conspiracy charges for making petrol bombs to use against racists. They argued they were acting in selfdefence - and won, when the jury accepted this as the case.
} 
racismo e xenofobia que eclodiram em diversos países do mundo, desde a década de 60, acabou por propiciar um clima de segregação e de intolerância mútua, por parte das minorias -, tem, também, por objetivo a construção de uma via dialógica necessária para o desenvolvimento do tema proposto.

A principal crítica que se insurge ao multiculturalismo seria a de que o Estado, na tentativa de afastar a intolerância cultural, teria se retirado de sua posição de mediador dos conflitos favorecendo a uma super-integração e fechamento dos grupos que compunham as minorias em seguimentos sociais autônomos, estanques e incomunicáveis. O argumento é válido, mais não retira, per se, a importância metodológica da teoria, que mostrou-se importante em considerar os grupos em si mesmos e não sobre um paradigma universal imposto, forjado sob fundamentos desprovidos de criticidade.

Por fim, e não menos importante, é a abordagem feita sobre a terminologia científica utilizada como supedâneo à epistemologia empregada para conferir melhor

Faced with this growing militancy, Bradford council drew up GLC-style equal opportunity spiked-politics | Article | The trouble with multiculturalism statements, established race relations units and began funding black organisations. A 12-point race relations plan declared Bradford to be a 'multiracial, multicultural city', and stated that every section of the community had 'an equal right to maintain its own identity, culture, language, religion and customs'.

As racism intensified through the Thatcher years, Bradford Asians became increasingly bitter. But the character of anti-racist protests in the city changed. By the mid-1980s the focus of concern had shifted from political issues, such as policing and immigration, to religious and cultural issues: a demand for Muslim schools and for separate education for girls, a campaign for halal meat to be served at school, and, most explosively, the confrontation over the publication of Salman Rushdie's The Satanic Verses.

This process was strengthened by a new relationship between the local council and the local mosques. In 1981, the council helped set up and fund the Bradford Council of Mosques. By siphoning resources through the mosques, the council was able to strengthen the position of the more conservative religious leaders and to dampen down the more militant voices on the streets. As part of its multicultural brief to allow different communities to express their distinct identities, the council also helped set up two other religious umbrella groups: the Federation for Sikh Organisations and the Vishwa Hindu Parishad, both created in 1984.

The consequence was to create divisions and tensions within and between different Asian communities, as each fought for a greater allocation of council funding.

There had always been residential segregation between the black and white communities in Bradford, thanks to a combination of racism, especially in council house allocation, and of a desire among Asians to find protection in numbers. But within Asian areas, Muslims, Sikhs and Hindus lived cheek by jowl for much of the postwar period.

In the 1980s, however, the three communities started dividing. They began increasingly to live in different areas, attend different schools and organize through different institutions. New council-funded community organizations and youth centres were set up according to religious and ethnic affiliations.

By the early 1990 s even the Asian business community was institutionally divided along community lines, with the creation in 1987 of the largely Hindu and Sikh Institute of Asian Businesses; of the Hindu Economic Development Forum in 1989; and of the Muslim-dominated Asian Business and Professional Club in 1991. The Asian Youth Movement, the beacon in the 1970s of a united struggle against racism, was split up and torn apart by such multicultural tensions. Multiculturalism was not simply the product of demand from black communities for their cultural differences to be recognised. That demand itself was to a large extent created through official policy in response to the black militancy of the 1970s and early 1980s. Instead of tackling headon the problems of racial inequality, social deprivation and political disaffection, the authorities, both national and local, simply encouraged communities to pursue what one of the recent reports into the summer 2001 riots calls 'parallel lives'. By the 1990 s multiculturalism had become generalised from a response to militant antiracism to a general recipe for society. Whereas in the 1950s British identity was seen in racial terms, by the 1990s the very notion of a national identity was questioned. Britishness became simply the ability to tolerate different identities. Little wonder, then, that people should increasingly look inwards to their religion, ethnicity or community as an affirmation of who they are. In places like Bradford, Oldham and Burnley, multiculturalism has helped segregate communities far more effectively than racism. Racism certainly created deep divisions in these towns. But it also helped generate political struggles against discrimination, the impact of which was to create bridges across ethnic, racial and cultural divisions. Multiculturalism, on the other hand, has not simply entrenched the divisions created by racism, but made cross-cultural interaction more difficult by encouraging people to assert their cultural differences. In spiked-politics | Article | The trouble with multiculturalism . http://www.spiked-online.com/Printable/00000002D35E.htm 6/12/2010. 
aplicabilidade aos fenômenos jurídicos, viabilizando a sua aplicação e o seu emprego no controle do discurso jurídico-científico.

A linguagem científico-jurídica não pode ser desprezada, haja vista tenha sido o principal meio utilizado pelo pensamento jurídico para justificar o discurso do Direito, eivando-o de cientificidade por meio das categorias lógicas, para que adquirisse, como ciência social, a autoridade fundamental para a regulação das relações sociais dentro da matriz normativa com pretensão de validade.

Portanto, é absolutamente imperativo a avaliação da contemporaneidade dos conceitos jurídicos que foram tomados de empréstimo das ciências da natureza, no sentido de aferir a sua adequação aos modernos fenômenos sociais, bem como aferir a sua atualidade frente aos seus congêneres utilizados na química, na física e na matemática moderna. Termos como sujeito e objeto sofreram, na seara científica, um incremento em seu significado, de forma a se adequar aos novos tempos.

As considerações tecidas no presente trabalho também têm por objetivo aferir se os conceitos, já velhos decantados na dogmática jurídica, podem servir para operacionalizar uma visão relativa de Direitos Humanos, ou se será necessário lançar mão, guardadas as devidas proporções, das mesmas articulações filosóficocientíficas operadas sobre esses conceitos de forma a adequar ou, ao menos, apontar para uma nova forma de conhecimento do objeto ora em estudo, afim de retirar dele o máximo de funcionalidade quanto aos fins a que se destina.

Outro fator importante, ao se falar em relativização, é o contraponto necessário entre esse termo e o conceito de relativismo, que, longe de ser somente uma questão de sufixo, envolve conceitos afetos à áreas completamente díspares: enquanto o Relativismo faz menção a um campo de conhecimento predominantemente antropológico, Relatividade é o termo utilizado na linguagem da física, da química e da matemática para descrever um complexo pensamento científico nas ciências exatas e tem por objetivo a descrição de fenômenos, partindo de uma linguagem científica, que tem natureza complementar à linguagem positivista.

No Direito, referimo-nos, constantemente, a objeto, sujeito, existência e validade, conceitos que são operacionalizados a partir de uma perspectiva positivista. O objetivo não é destruir ou desconstruir o sistema para apresentar algo mirabolante ou incompreensível, mas somente integrar esses conceitos com outros, utilizando o mesmo paradigma e metodologia, com recurso à filosofia da ciência, 
para promover o translado dos termos semânticos da linguagem científiconaturalista, para as ciências do espírito e tentar colocá-lo em conformidade com o pensamento e a epistemologia normativa, no estado em que hoje se encontra.

Por fim, é forçoso acentuar que essas considerações singelas não tem por escopo um novo tratado sobre a possibilidade de conhecimento no Direito, ou se o Direito é ou não ciência, visa somente apontar para uma série de fatos e fenômenos que, dada a própria natureza e finalidade do Direito, demandam soluções práticas, com vistas a operacionalizar, organizar, conduzir e resolver conflitos direcionando a atuação estatal à promoção da paz social e do bem comum.

No entanto, essas soluções práticas, para adquirir validade precisam estar submetidas a um método de controle. Esse foi o nosso objetivo ao propor o hibridismo entre as Teorias da Ciência e da Linguagem, como fatores epistemológicos determinantes para o encontro de uma metodologia jurídica que pudesse servir de razão discursiva e os fundamentos históricos e antropológicos que serviriam de conteúdo essencial para se determinar a natureza dos atores envolvidos do processo, seja discursivo, seja na determinação do conteúdo racional discursivo que a prática dialógica, sob os pressupostos determinados acima, é capaz de propiciar. 


\section{Conclusão}

O presente trabalho teve por objetivo fazer uma conjunção entre teorias que aparentemente não seriam conciliáveis e demonstrar que suas bases epistemológicas repousavam sobre fundamentos idênticos. Esse foi o caso da Teoria da Relatividade e da Teoria da Ação Comunicativa, ambas assentadas sobre pressupostos de universalidades, que são estabelecidos a partir de uma relação intersubjetiva. No caso da Relatividade, os observadores inerciais, e os sujeitos da relação discursiva, para a Teoria da Ação Comunicativa.

Foram levantadas possibilidades de submissão de um conteúdo jurídico de natureza histórica e antropológica a uma metodologia científica relativista, nos moldes da Teoria da Relatividade, visando a formulação científica de um conjunto de direitos por meio de uma metodologia que não enfraquecesse o conteúdo originário dos mesmos.

Como foi demonstrado, todas as vezes em que, nas ciências jurídicas, fez-se menção à relatividade de direitos, fez-se em detrimento ao próprio conteúdo essencial, por não dizer, em desfavor da integridade ontológica da norma ou do direito envolvido. Esse efeito é devido, em grande parte, à influência do positivismo jurídico, que determina que a norma, possuindo uma existência ontológica absoluta, não está passível de ensejar uma solução que não seja consentânea com a sua natureza absoluta. O que, por muitas vezes, vai fazer com que o fato real se renda, incondicionalmente, à norma jurídica, e o conflito, como realidade fática, venha a sofrer com o excesso de formalismo de que se está revestida a norma positiva.

Ao conjugar as teorias que acima foram expostas, nosso objetivo foi, apenas, demonstrar que é possível, sem negar o fato social, que pode ser aferido por meio de uma investigação tanto científica, quanto antropológica, lançar mão de determinados métodos para se produzir um fator de racionalidade que, não influenciando pelo conteúdo do fato social, é capaz de lhe render um elemento racional.

A relatividade, aqui introduzida, teve o escopo de demonstrar que esse fator de racionalidade não pode existir dentro do próprio sujeito, como uma ontologia do próprio sujeito, mas sim como elemento de uma atividade relacional em que sejam respeitadas todas as partes integrantes. Nesse ponto, estão de acordo tanto a Teoria da Relatividade, quanto a teoria habermasiana do Agir Comunicativo. 
Foi escolhida a Teoria do Agir Comunicativo porque ela, a exemplo do que vimos acontecer da física, pressupõe um elemento de racionalidade que não envolve, nem influencia os elementos ontológicos do sujeito, porém, participa, ativamente, da relação dialógica.

Como é possível depreender, a referida teoria segue os mesmos pressupostos epistemológicos, guardadas as devidas proporções e a natureza das duas teorias, que aqueles sobre os quais se baseavam os fundamentos relacionais que deram ensejo ao cálculo do elemento racional $k$, a que nos referimos em nosso capítulo sobre a Relatividade.

Desse modo, a teoria habermasiana desenvolve-se segundo duas perspectivas: a primeira parte da afirmação do "princípio da universalização U", que exige, para a validação do pressuposto normativo, a previsão de que as conseqüências e efeitos colaterais de seu seguimento geral para a satisfação de interesses pessoais possam ser aceitos, por todos envolvidos. A essa idealização, implicitamente assumida, acresce-se a necessidade de que os pressupostos normativos, em sua projeção ideal, sejam implementados em discursos práticos reais, e pois, sujeitos a um teste de validade continuado.

Da aplicação do método e do sentido histórico-antropológico, conclui-se que da maneira como os argumentos sobre os Direitos Humanos foram forjados, no bojo da cultura ocidental européia, tende-se a conferir-lhes um conteúdo que não permite negar a essencialidade desses direitos. Tal fato inviabiliza a inscrição desses direitos numa agenda que vise à sua atuação como argumento integrante de um discurso que vise a formatar um consenso, envolvendo outros interlocutores, que, valendo-se da mesma perspectiva de que esses direitos são, ontologicamente, imanentes às suas culturas, não estarão dispostos a aceitar um elemento consensual a que se poderá conferir a racionalidade necessária para a formatação de um discurso de controle normativo em matéria de Direitos Humanos.

Somente quando cada interlocutor abandonar a sua pretensão de universalidade - com relação ao conteúdo de direitos do homem, ou Direitos Humanos, que tem como pressuposto formativo seus próprios valores antropológico, sociais, e morais, sem, no entanto, enfraquecer os pressupostos pelos quais esses valores ganham validade no interior de cada grupo social - é que será possível a propagação dos Direitos Humanos como um fundamento racional universal para 
todas as culturas, desde que todas participem do processo discursivo, nos quais sejam assegurados 0 conjunto de pressupostos pragmáticos normativos garantidores, genericamente, das condições ideais de liberdade e igualdade entre os povos. 


\section{REFERÊNCIAS}

ARISTÓTELES; GIGON, Olof. Politik und Staat der Athener. Zurich: Artemis 1955.

ARNDT, Christina. Die Menschenrechte - partikularistische Ansätze zur Begründung ihrer Universalität- Dissertation zur Erlangung des Grades der Doktorin der Philosophie im Fachbereich Philosophie und Sozialwissenschaften der Universität Hamburg, Hamburg, Hamburg 2000.

BARBOZA, Márcia Noll. "parte I: Direito e Moral". In: O Princípio da Moralidade Administrativa: uma abordagem de seu significado e suas potencialidades à luz da noção de moral crítica. Porto Alegre: Livraria do Advogado, 2002.

BARROSO, Luis Roberto. Interpretacao e aplicacao da constituicao: Fundamentos de uma dogmatica constitucional transformadora. Sao paulo: Saraiva, 1999.

BENVINDO, Juliano Zaiden. Racionalidade Jurídica e Validade normativa: da metafísica à reflexão democrática. Belo horizonte, MG: Argvmentum, 2008.

BERREMAN, Gerald.Ethics versus Realism in Anthropology. In Ethics and the Profession of Anthropology. C. Fluehr-Lobban, ed. 1991. Philadelphia: University of Pennsylvania Press.

BIELEFELDT, Heiner. "Western" versus "Islamic" Human Rights Conceptions?: A Critique of Cultural Essentialism in the Discussion on Human Rights Political Theory, Vol. 28, No. 1. (Feb., 2000), pp. 90-121.

BOBBIO, Norberto. O Positivismo Jurídico: lições de Filosofia do Direito.Tradução e notas: Márcio Pugliesi, Edson Bini e Carlos E. Rodrigues. São Paulo: ícone, 1999.

DUMONT, Louis. . HOMO AEQUALIS: GENESE E PLENITUDE DA IDEOLOGIA ECONOMICA.Trad. de José Leonardo Nascimento. São Paulo: EDUSC, 2000.

EINSTEIN, Albert. The principle of relativity: A collection of original memoirs on the special and general theory of relativity. New York: Dover Publications, 1923. $216 \mathrm{p}$.

FIGUEIRA, Ricardo Rezende. Pisando Fora da Própria Sombra: A escravidão por dívida no Brasil. Rio de Janeiro: Civilização Brasileira, 2004.

HABERMAS, Jürgen, Erläuterung zum Begriff des kommunikativen Handels in Philosophische Texte Band 2. Sudienausgabe Suhrkamp. Suhrkamp. Frankfurt am Main. 2001.

KELSEN, Hans. "Direito e Moral". In: Teoria Pura do Direito. Tradução: João Baptista Machado. 5a ed. São Paulo: Martins Fontes, 1996.

LEIRNER, Piero de Camargo. Hierarquia e individualismo em Luís Dumont. Rio de Janeiro : Jorge Zahar Ed., 2003. 
LORENZETTI, Ricardo Luiz. Teoria da Decisão Judicial: Fundamentos de DireitoSão Paulo. Editora Revista dos Tribunais.2009.

MALIK, Kenan The trouble with multiculturalism : Official multicultural policies have been even more divisive than old-fashioned racism. Disponível em http://www.spiked-online.com/Printable/00000002D35E.htm em 6/12/2010.

MASTRONARDI, Philippe, Recht und Kultur: Kulturelle Bendigtheit und Universaler Anspruch des juristischen Denkens. Disponível em http://www.zaoerv.de. 2001, Max-Planck-Institut für ausländisches öffentliches Recht und Völkerrecht.

NEWTON-SMITH, Lógica, Um Curso Introdutório, Gradiva Publicações, 2005.

SAYKHAM, Voladet. Das Menschenrecht bei Immanuel Kant- Dissertationsarbeit zur Erlangung des akademischen Grades eines Dr. phil. Humboldt Universität zu Berlin Philosophische Fakultät, 2000.

SCHMALE, Wolfgang 1993: Human Rights in the Intercultural Perspective and the Reorganization of the International Debate. In: ders. (Ed.): Human Rights and Cultural Diversity. Europe, Arabic-Islamic World, Africa, China. Goldbach: Kneip. 